\title{
DESIGN, ANALYSIS, AND OPTIMIZATION OF A RADIOISOTOPE THERMOPHOTOVOLTAIC (RTPV) GENERATOR AND ITS APPLICABILITY TO AN ILLUSTRATIVE SPACE MISSION
}

\author{
A. Schock \\ M. Mukunda, C. Or, V. Kumar, G. Summers \\ of Orbital Sciences Corporation \\ (formerly of Fairchild Space and Defense Corporation) \\ Germantown, MD 20874, U.S.A.
}

Presented at the International Astronautical Federation Congress

October 1994

Jerusalem, Israel 


\section{INTRODUCTION}

- Thermophotovoltaic (TPV) generators are derivatives of photovoltaic (PV) solar systems.

- PV systems convert solar radiation into electricity. TPV systems convert infrared radiation from a heat source into electricity. RTPVs are TPVs using a radioisotope heat source.

- RTPV concept has been recognized for some time, but materials permitting competitive efficiencies only became available recently.

- Solar cells are optimized for the solar spectrum. TPV cells must be optimized for infrared spectrum at practical temperatures.

- Boeing personnel have proposed and performed preliminary performance measurements of GaSb cells and spectrally selective gold filters for RTPVs.

- These were the basis of Fairchild's system design and optimization study reported here. 


\section{APPLICATION TO PLUTO FAST FLYBY MISSION}

- The Fairchild study deals with a design and thermal, electrical, and structural analysis of an integrated system consisting of:

- a canistered radioisotope heat source

- $\quad$ an array of TPV converter cells

- $\quad$ an optimized radiator for heat rejection

- To focus the RTPV study, the system is designed for a specific mission, Pluto Fast Flyby (PFF), under study by JPL for a possible 2000/2001 launch.

- That mission is an excellent example of NASA's trend toward smaller, lighter, and cheaper spacecraft and subsystems.

- The mission's goal is to send small spacecraft to reconnoiter Pluto, the only unexplored planet in our solar system, together with its large moon Charon.

- Two flyby probes would obtain visual images, infrared and ultraviolet data, and radio observations of both sides of the planet/moon system, to map their surface composition and atmospheric structure.

- The use of small spacecraft would permit direct flights, without gravity-assistance maneuvers, to reach Pluto in $\sim 8$ years, before the collapse of the planet's atmosphere.

- The principal science data would be collected and stored during a brief flyby, to be down linked back to Earth during a post-encounter cruise of up to 1 year. 
COMPARITIVE SIZE OF CASSINI AND PLUTO SPACECRAFT

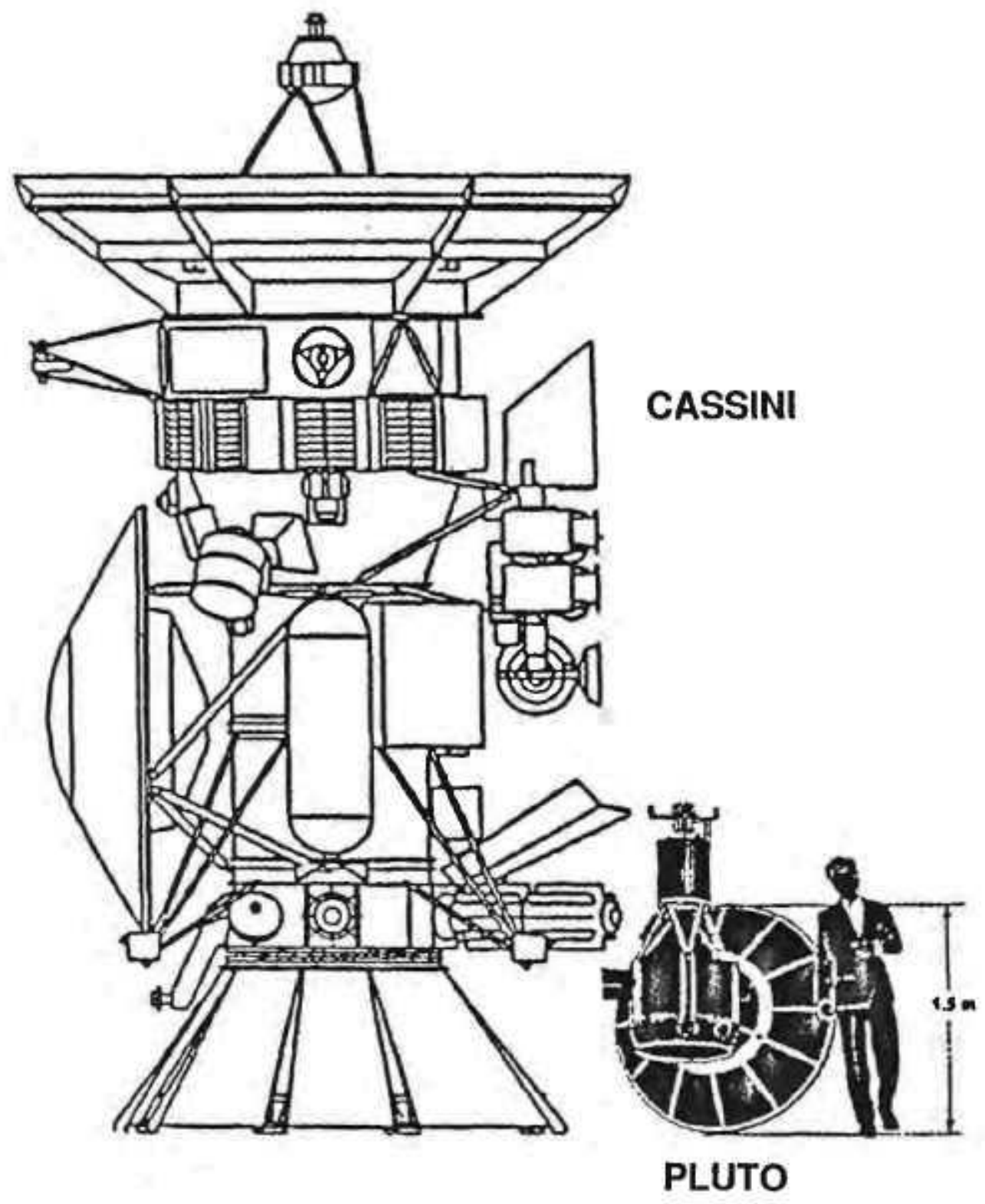




\section{PFF SPACECRAFT}

- The main spacecraft design problem is minimizing cost and mass without increasing duration of pre- and post-encounter cruise, by use of advanced technologies.

- Since solar flux at Pluto is only one thousandth that at Earth, JPL's baseline design stipulated the use of a radioisotope power system (RPS), with a major mass reduction goal.

- To support the JPL study, the U.S. Department of Energy commissioned Fairchild Space to prepare integrated system designs of various RPS options, to analyze their performance and to assess their technological maturity.

- The results of studies on five thermoelectric options and three Stirling options were reported previously.

- The present report describes and compares results for the RTPV option. 


\section{JPL Mass Assumptions (kg)}

\begin{tabular}{|ll|c|c|c|}
\hline & & Baseline & Goals & $\Delta$ \\
\hline Spacecraft (Wet) & & 164.1 & 112.4 & $31 \%$ \\
\hline Power System & 23.5 & 12.5 & $47 \%$ \\
\hline Shunt Regulator & 1.0 & & & \\
Discharge Controller & 1.2 & & & \\
Power Distribution & 1.5 & 5.7 & $3.0(5.7)$ & $47 \%(0 \%)$ \\
Power Controller & 0.5 & & & \\
Power Converter & 0.6 & & & \\
Pyro Switching Unit & 0.8 & & $9.5(6.8)$ & $47 \%(62 \%)$ \\
\hline Radioisotope Power Source & & 17.8 & &
\end{tabular}




\section{RTPV DESIGN DESCRIPTION}

- Radioisotope Heat Source

- Thermophotovoltaic Converter

- Heat Rejection System

- System Design

- Integration with PFF Spacecraft 


\section{GPHS}

\section{GENERAL-PURPOSE HEAT SOURCE MODULE (250 WATTS) Sectioned at Mid-Plane}

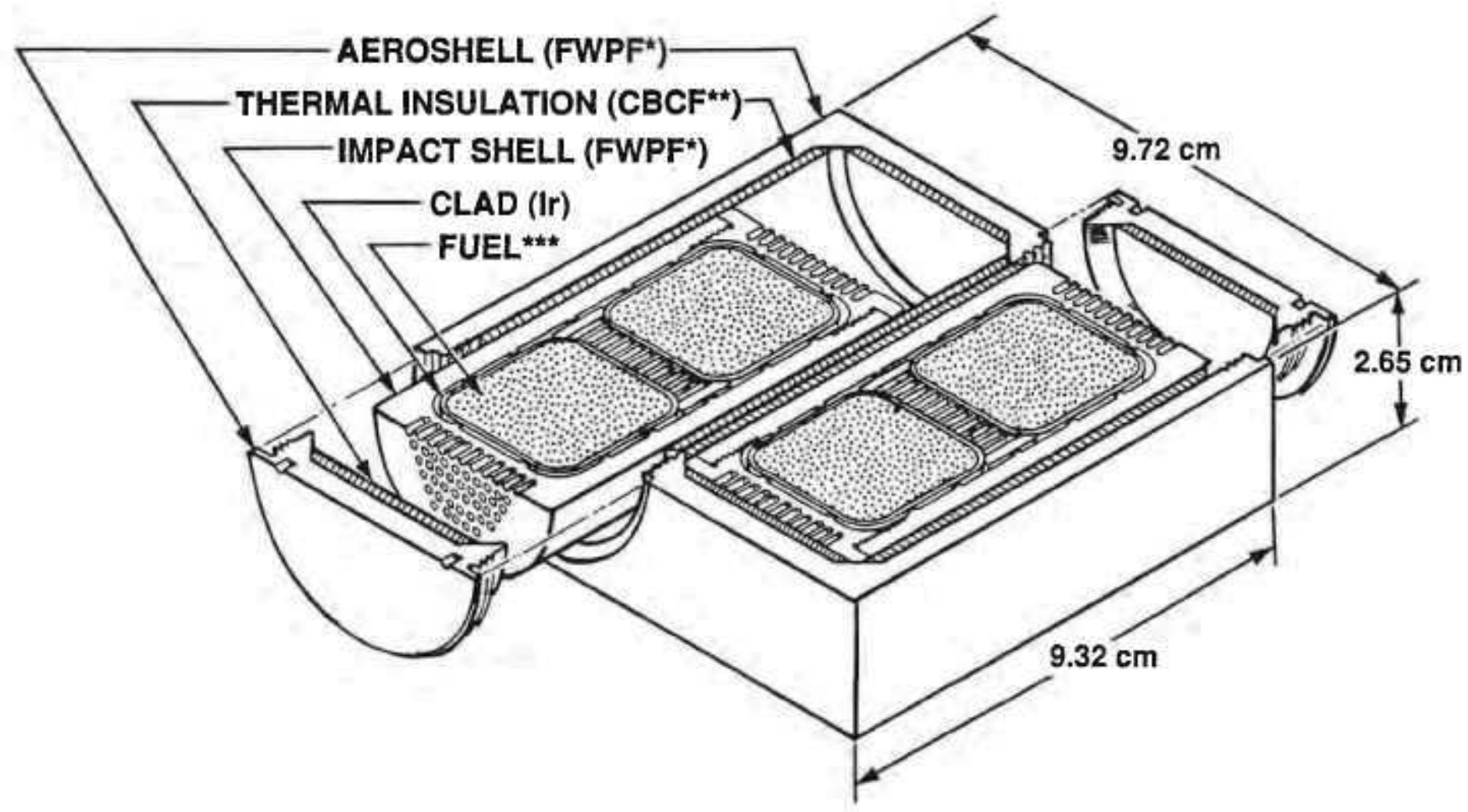

*Fine-Weave Pierced Fabric, a 90\%-dense 3D carbon-carbon composite **Carbon-Bonded Carbon Fibers, a 10\%-dense high-temperature insulator ***62.5-watt ${ }^{238} \mathrm{PuO}_{2}$ pellet

- RTPV heat source consists of two GPHS modules, identical to those used on Galileo, Ulysses, and upcoming Cassini missions.

- This is a $60 \%$ reduction from the five modules used in the RTG design for PFF.

- GPHS modules have undergone very extensive safety analyses, tests, and reviews. These need not be repeated as long as the PFF launch vehicle is no more severe than the Shuttle or Titan-4. 


\section{HORIZONTAL CROSS-SECTION OF CONVERTER Dimensions in Inches}

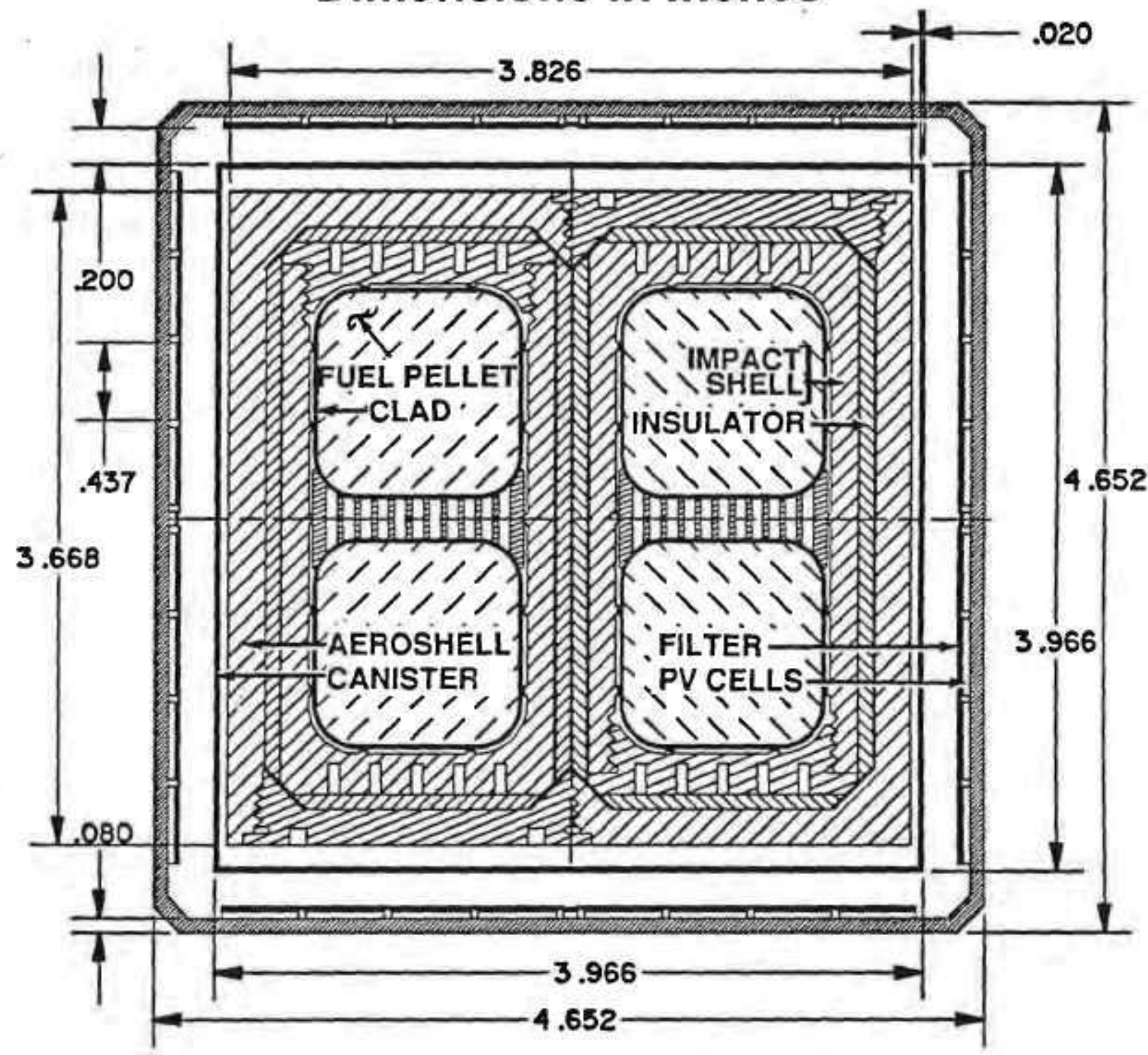

- Converter cells with filters are mounted on inside of housing, $8 \times 8$ on each side wall.

- Heat source is completely enclosed in sealed canister, to prevent access of outgassing and sublimation products to converter cells.

- Outside of Mo canister is coated with $\mathrm{W}$, to minimize sublimation. 


\section{VERTICAL CROSS-SECTION OF CONVERTER}

\section{Dimensions in Inches}

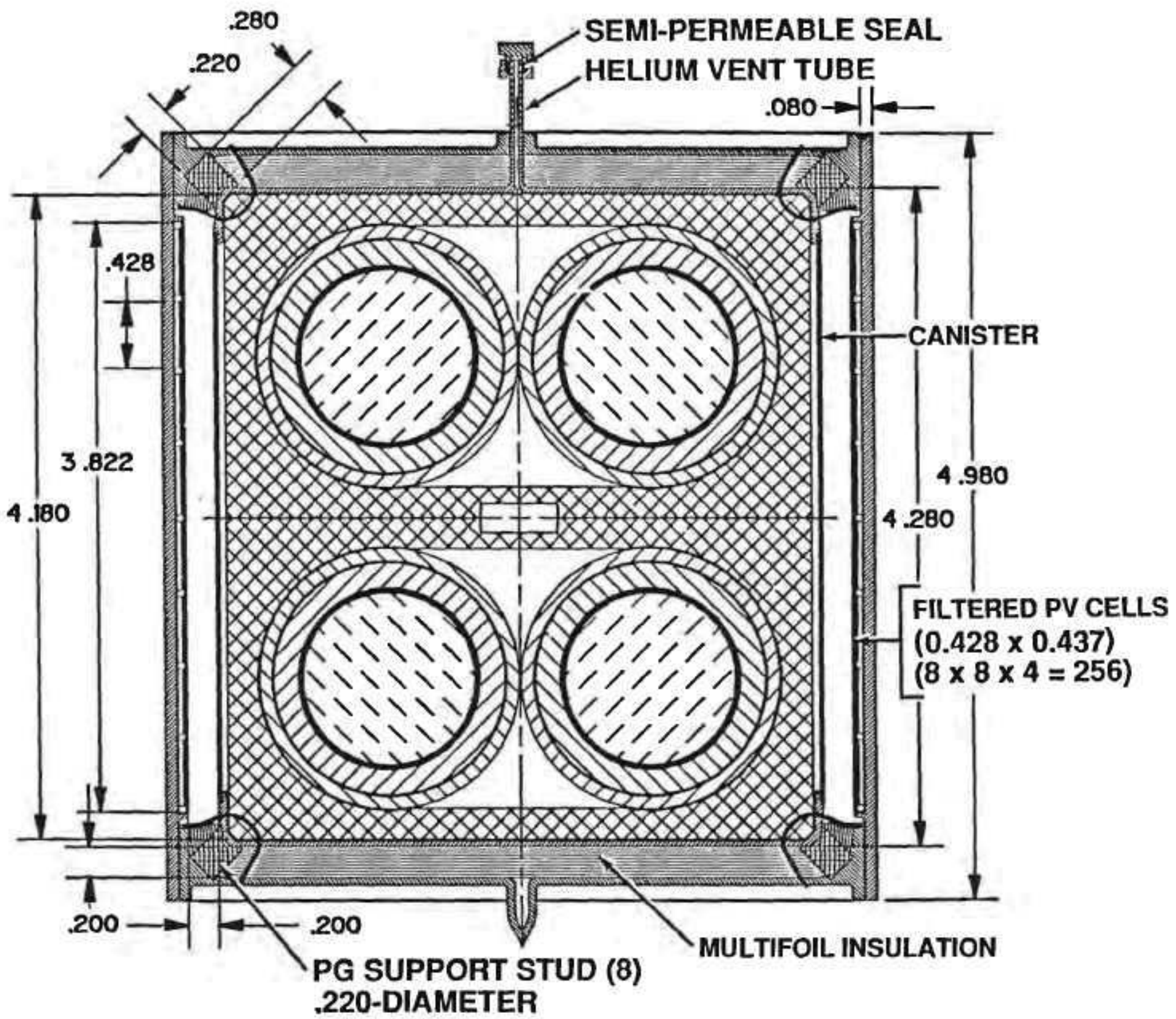


SCHEMATIC VIEW OF SERIES-PARALLEL NETWORK CONNECTING THE 64 PV CELLS ON EACH CONVERTER FACE
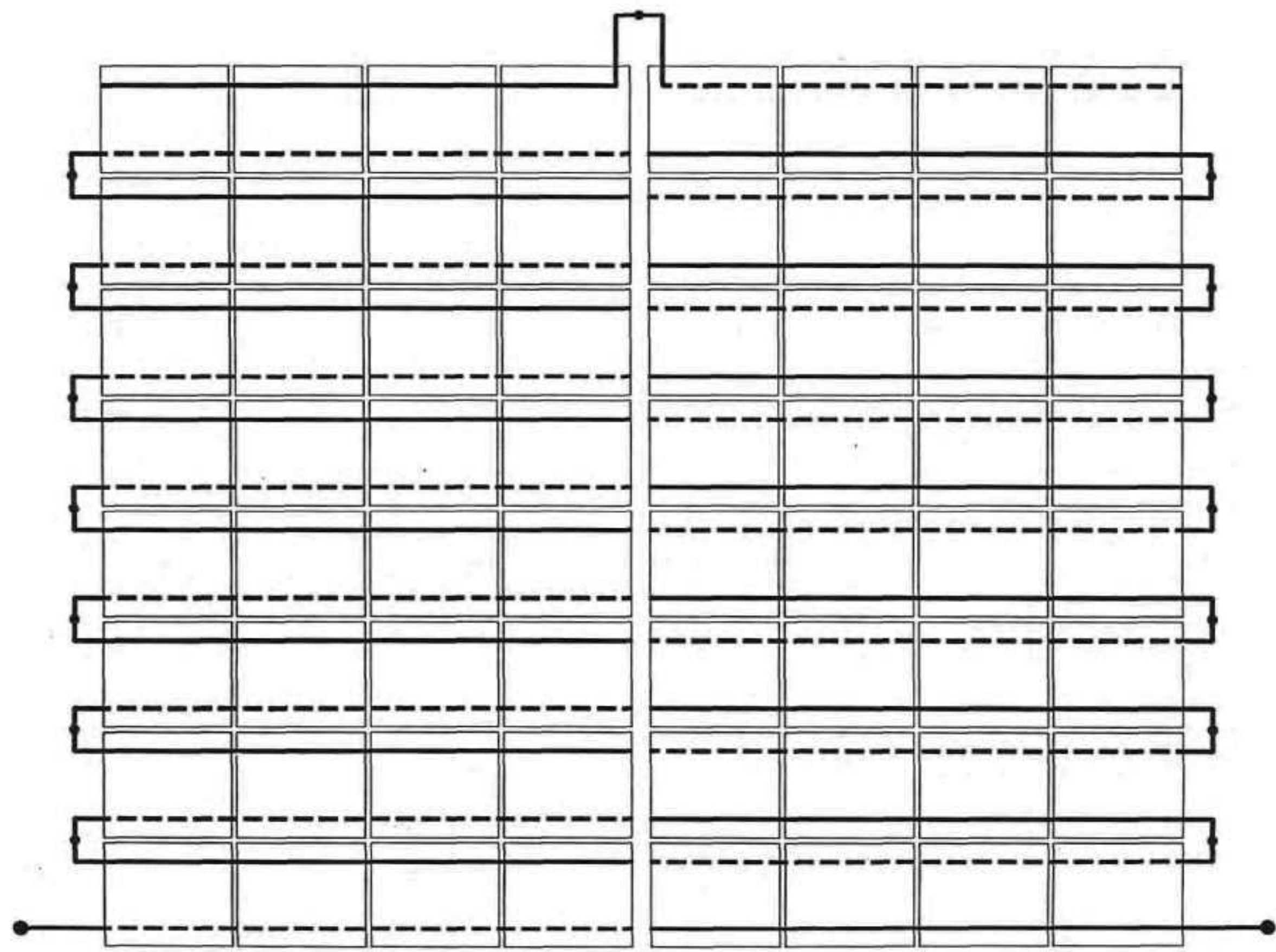


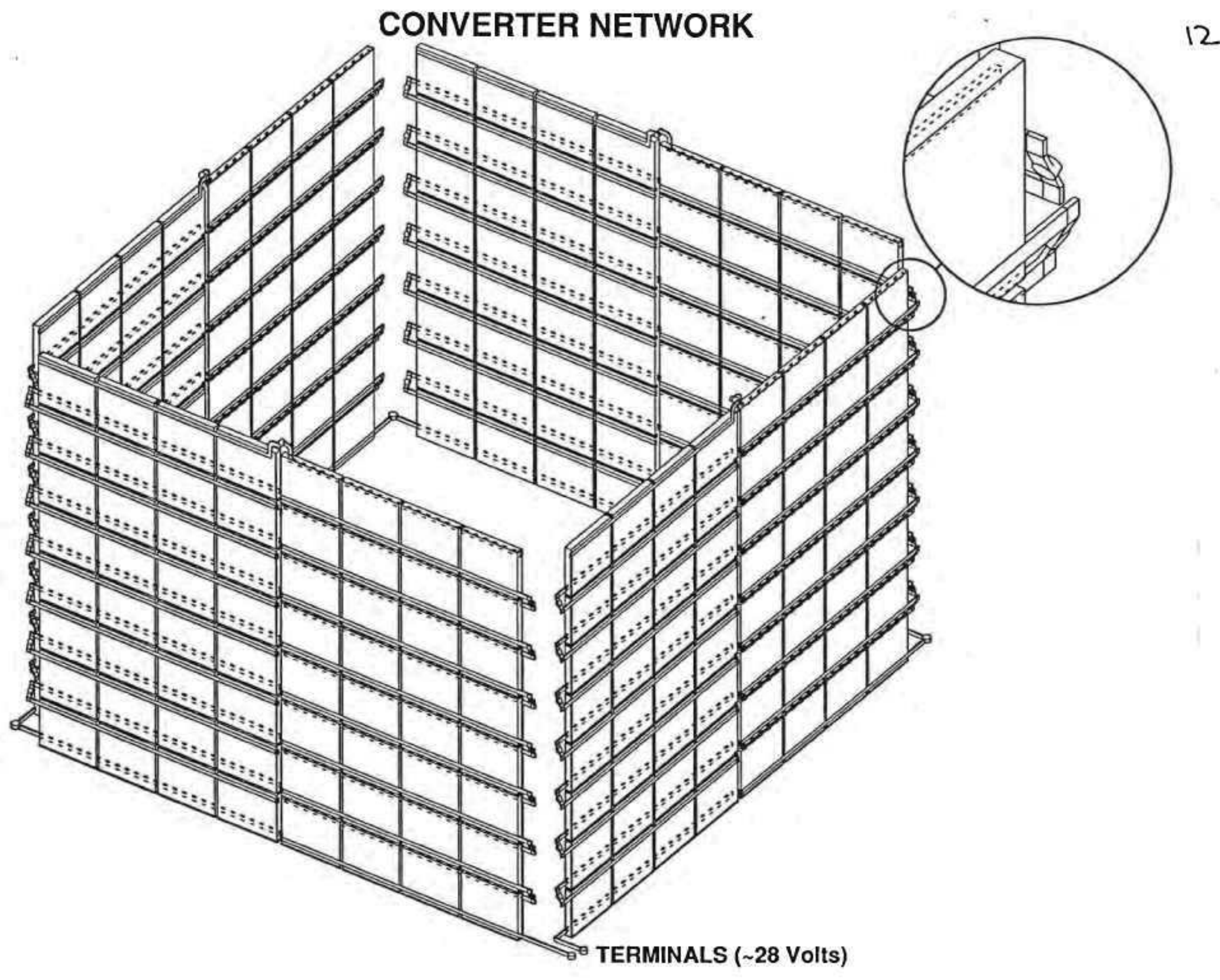


EXPLODED VIEW OF CONVERTER

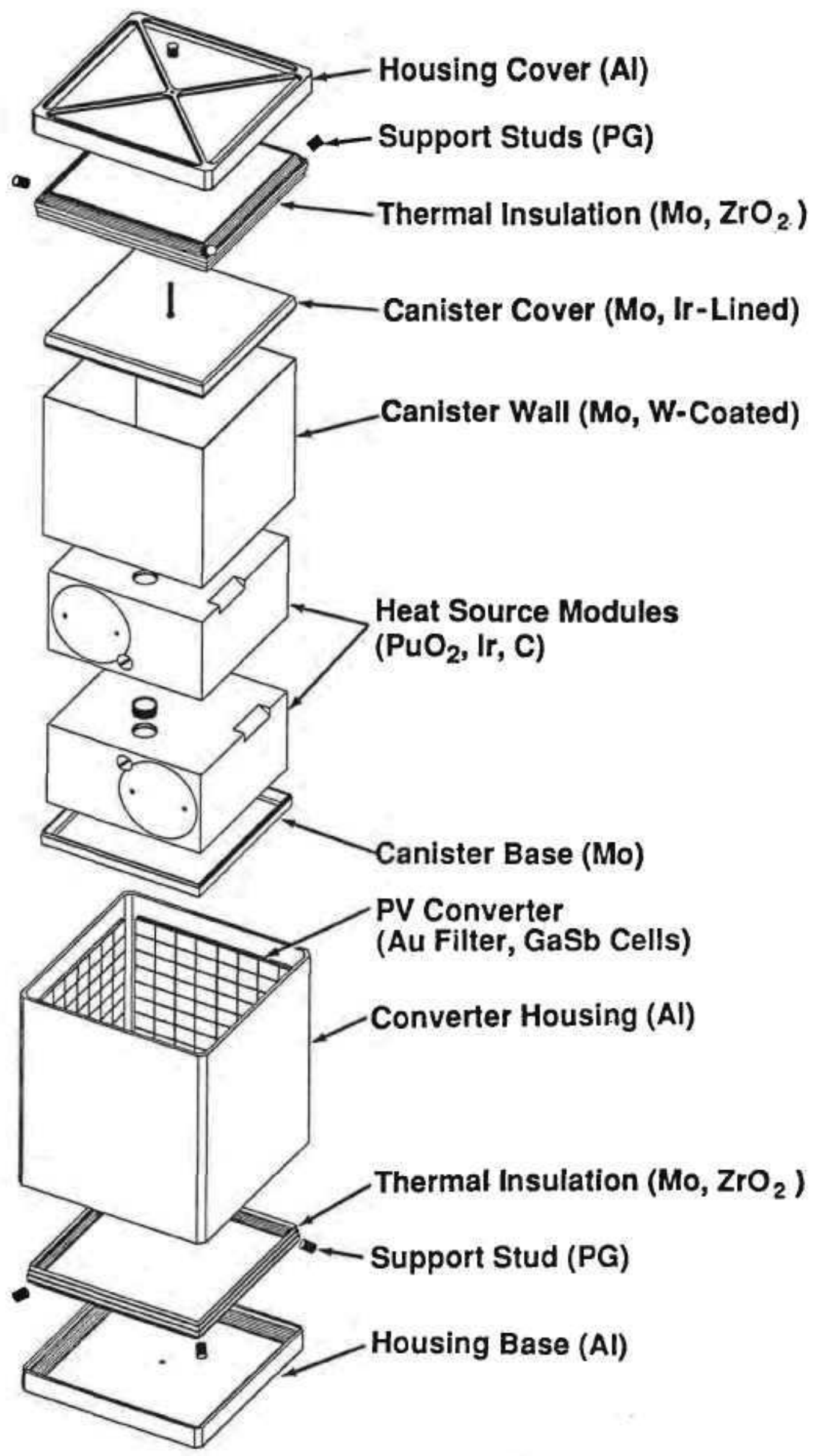


EXPLODED VIEW OF RTPV GENERATOR AND OF RADIATOR FIN

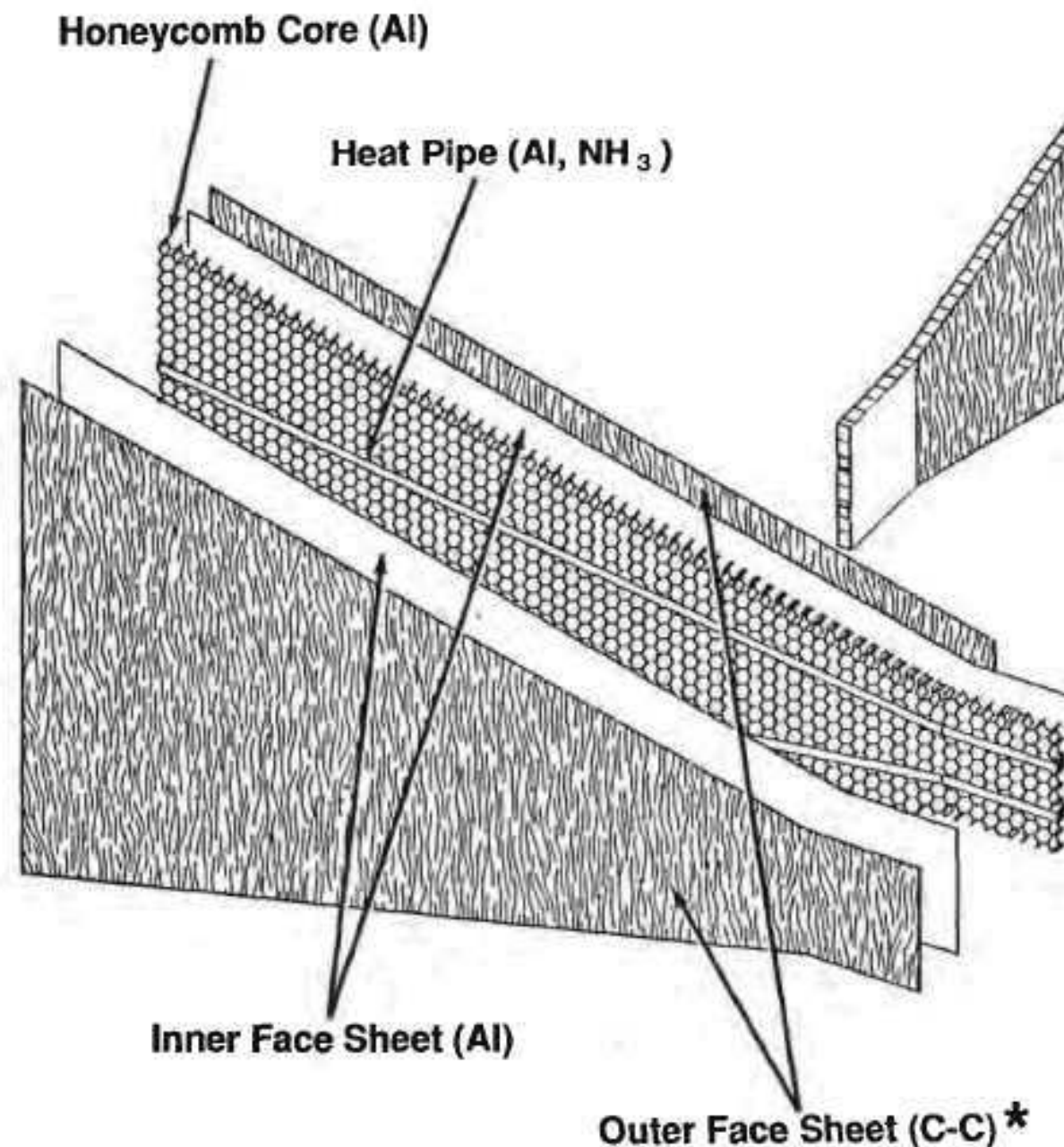

* A graphitized carbon-bonded carbon-fiber structure developed by SAIC for NASA/Lewis, which has twice the thermal conductivity of copper at about one fourth of its density 


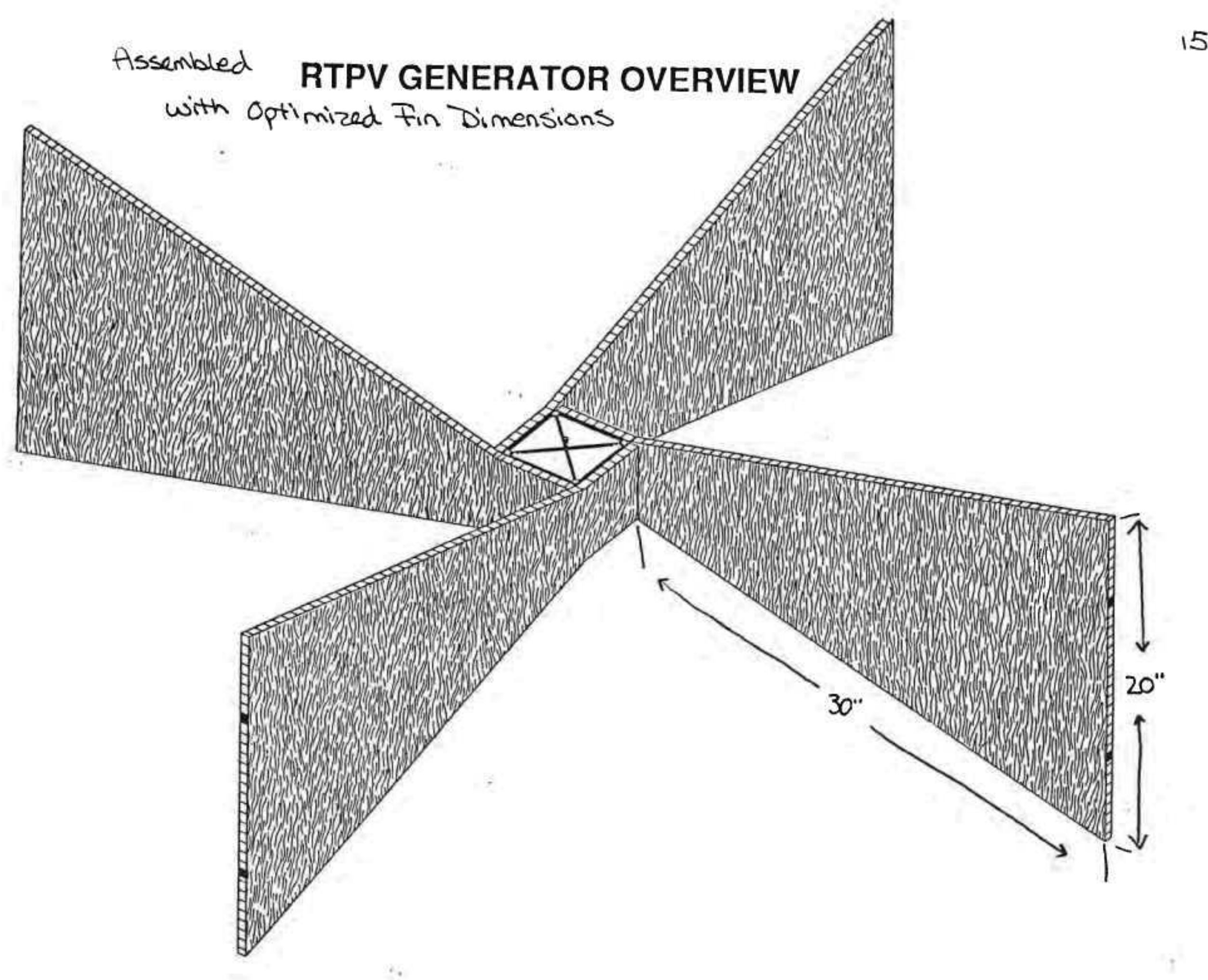




\section{OPTIMIZED RTPV GENERATOR MOUNTED ON TOP OF PFF SPACECRAFT}
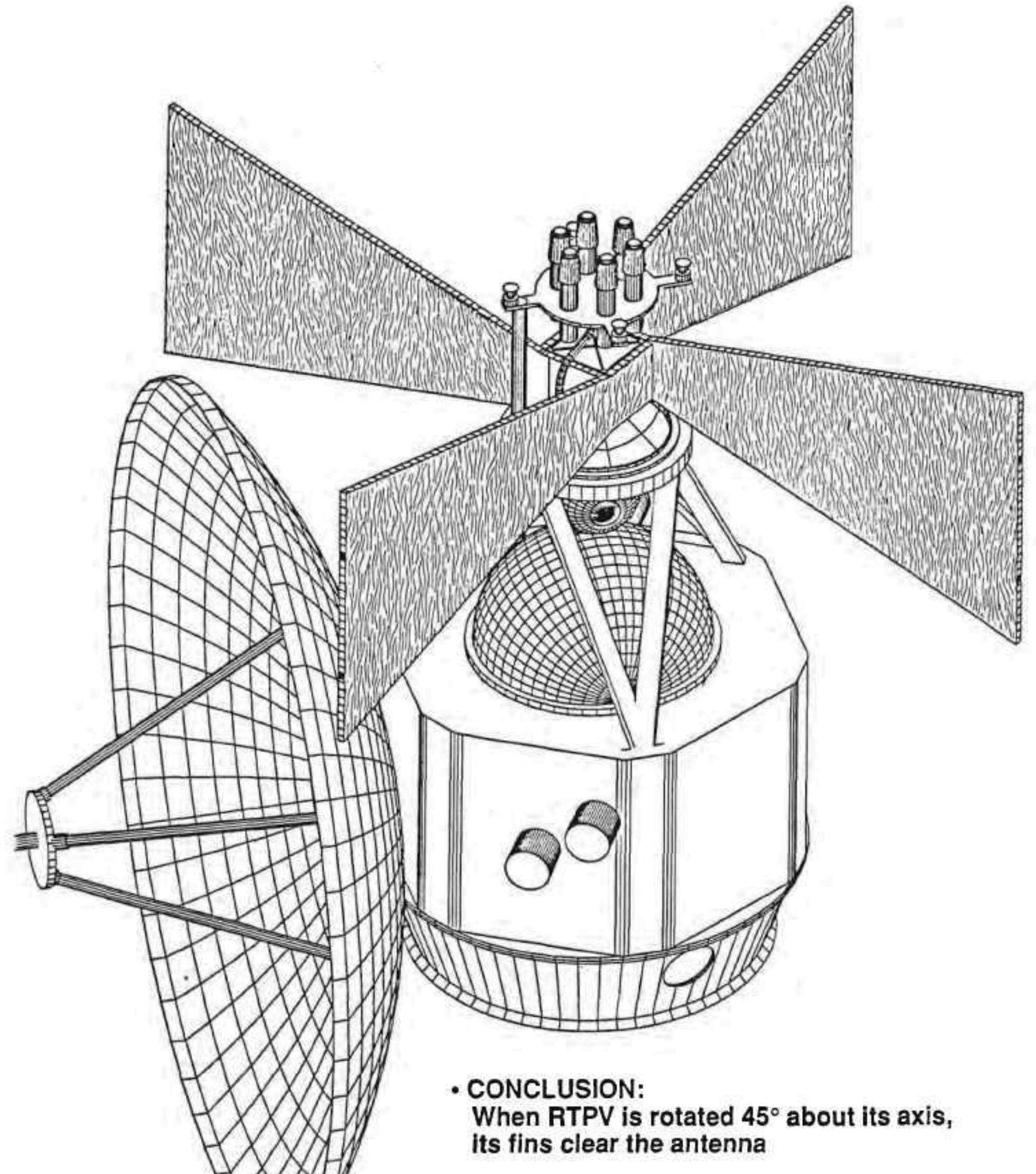


\section{MATING OF RTPV RADIATOR WITH PFF S/C ANTENNA}

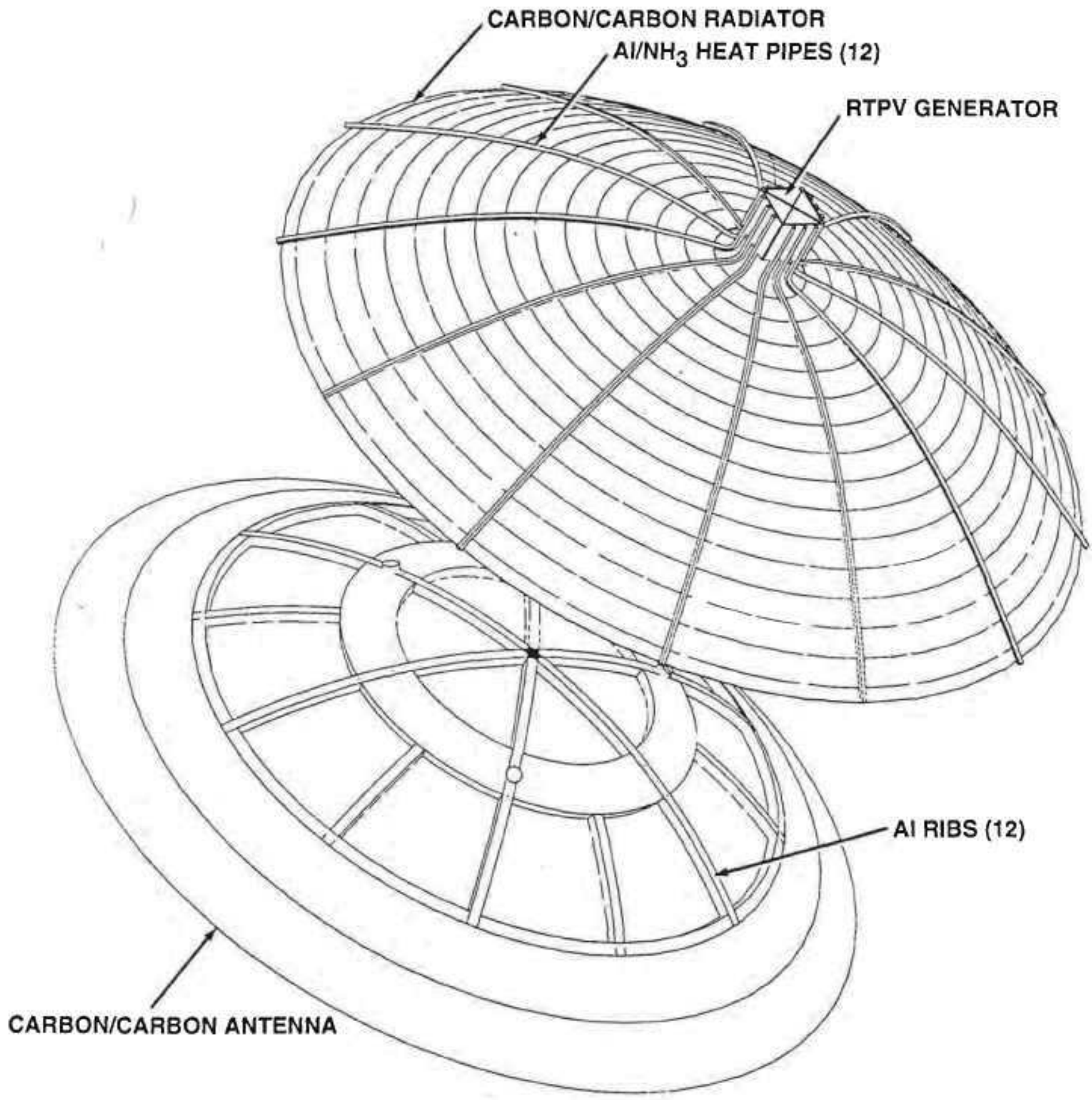




\section{FIT OF COMBINED RADIATOR / ANTENNA IN PFF PROTON LAUNCH VEHICLE}

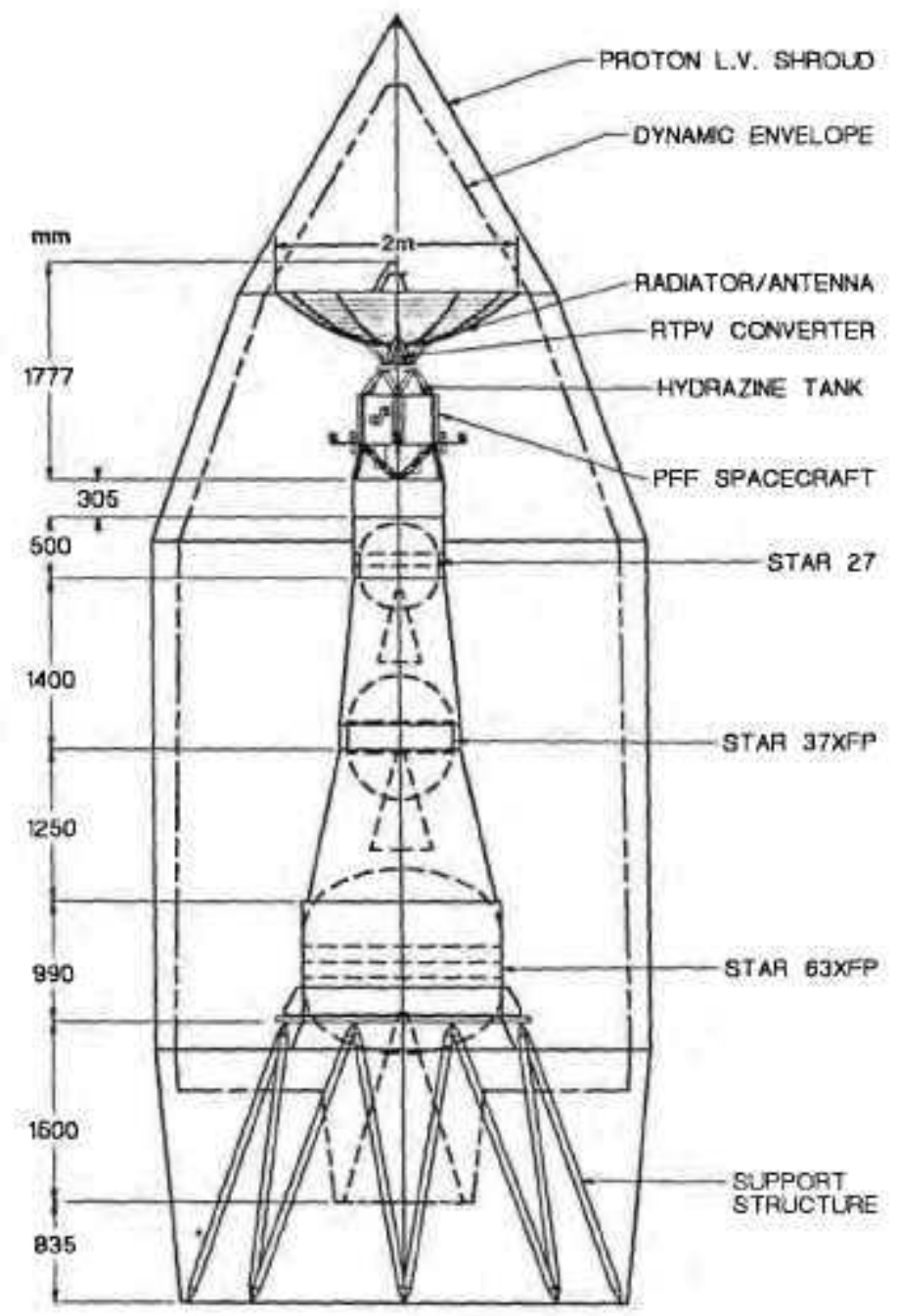




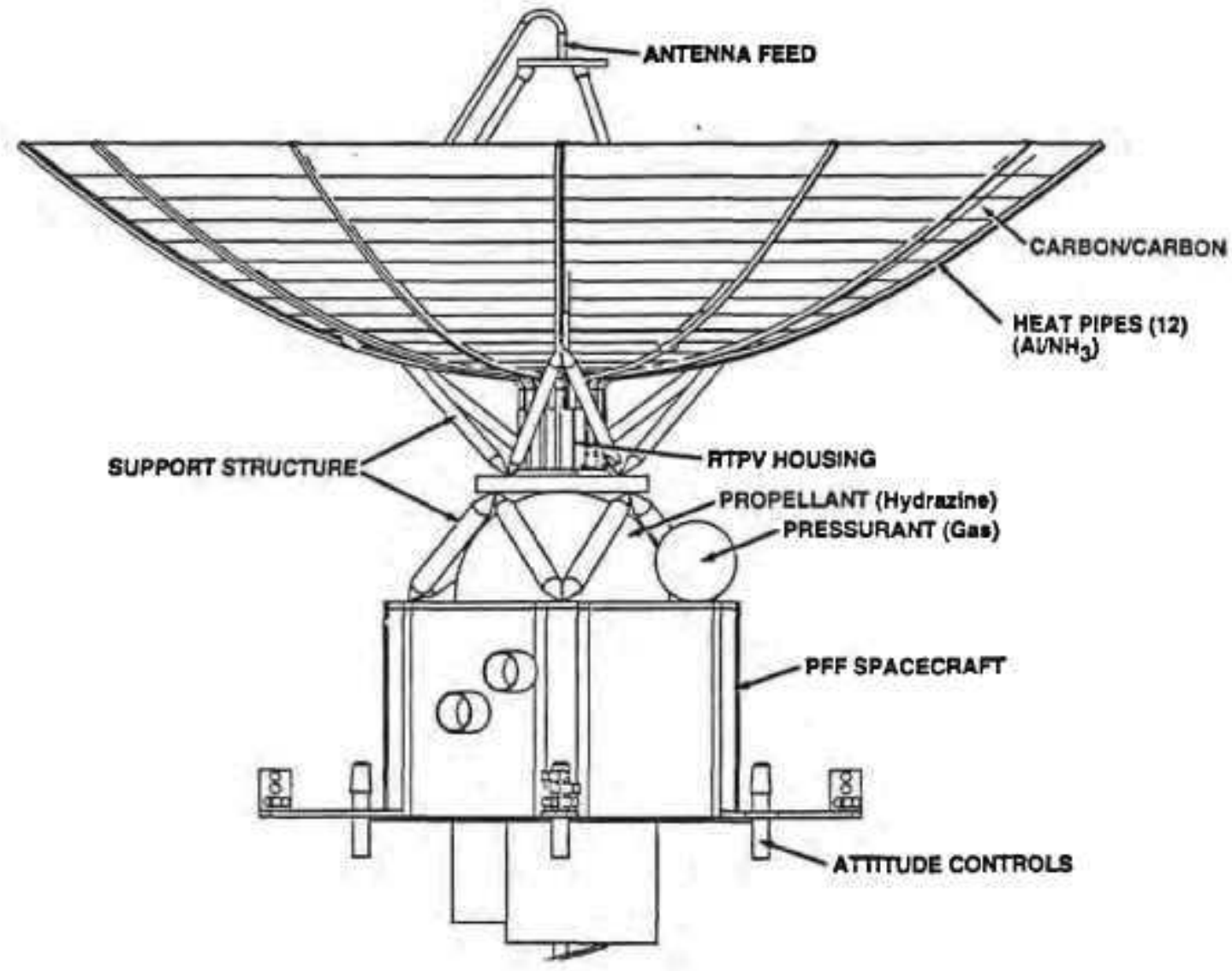




\section{RADIATIVE ENERGY TRANSFER ANALYSIS}

Black-Body Emission:

$$
q(\lambda) d \lambda=\frac{2 \pi h c^{2} \lambda^{-5} d \lambda}{\exp (h c / \lambda k T)-1}
$$

Energy Flux Leaving Source (S) and Converter (C):

$$
\begin{aligned}
& q_{s}(\lambda) d \lambda=\varepsilon_{s}(\lambda) \frac{2 \pi h c^{2} \lambda^{-5} d \lambda}{\exp \left(h c / \lambda k T_{s}\right)-1}+R_{s}(\lambda) q_{c}(\lambda) d \lambda \\
& q_{c}(\lambda) d \lambda=\varepsilon_{c}(\lambda) \frac{2 \pi h c^{2} \lambda^{-5} d \lambda}{\exp \left(h c / \lambda k T_{c}\right)-1}+R_{c}(\lambda) q_{s}(\lambda) d \lambda
\end{aligned}
$$

Net Energy Transfer from Source to Converter:

$$
\begin{aligned}
q(\lambda) d \lambda & =\left[q_{s}(\lambda)-q_{c}(\lambda)\right] d \lambda \\
& =\frac{2 \pi h c^{2} \lambda^{-5}}{1-R_{s}(\lambda) R_{c}(\lambda)}\left[\frac{\varepsilon_{s}(\lambda)\left[1-R_{c}(\lambda)\right]}{\exp \left(h c / \lambda k T_{s}\right)-1}-\frac{\varepsilon_{c}(\lambda)\left[1-R_{s}(\lambda)\right]}{\exp \left(h c / \lambda k T_{c}\right)-1}\right] d \lambda \\
& =\frac{2 \pi h c^{2} \lambda^{-5}\left[\exp \left(h c / \lambda k T_{s}\right)-1\right]^{-1}}{\left[\varepsilon_{s}(\lambda)\right]^{-1}+\left\{\left[R_{c}(\lambda)\right]^{-1}-1\right\}^{-1}} d \lambda
\end{aligned}
$$




\section{PHOTOVOLTAIC CONVERSION}

Net Energy Flux:

$$
q(\lambda) d \lambda=\frac{2 \pi h c^{2} \lambda^{-5}\left[\exp \left(h c / \lambda k T_{s}\right)-1\right]^{-1}}{\left[\varepsilon_{s}(\lambda)\right]^{-1}+\left\{\left[R_{c}(\lambda)\right]^{-1}-1\right\}^{-1}} d \lambda .
$$

Absorbed Photon Flux:

$$
\phi_{p}(\lambda) d \lambda=\frac{q(\lambda) d \lambda}{h c / \lambda}=\frac{2 \pi \alpha c \lambda^{-4}\left[\exp \left(h c / \lambda k T_{s}\right)-1\right]^{-1}}{\left[\varepsilon_{s}(\lambda)\right]^{-1}+\left\{\left[R_{c}(\lambda)\right]^{-1}-1\right\}^{-1}} d \lambda
$$

Generated Electron Flux:

$$
\phi_{e}(\lambda) d \lambda=\phi_{p}(\lambda) Q(\lambda) d \lambda=Q(\lambda) \frac{2 \pi \alpha c \lambda^{-4}\left[\exp \left(h c / \lambda k T_{s}\right)-1\right]^{-1}}{\left[\varepsilon_{s}(\lambda)\right]^{-1}+\left\{\left[R_{c}(\lambda)\right]^{-1}-1\right\}^{-1}} d \lambda
$$

- Requires three sets of wavelength-dependent experimental data:

$\varepsilon_{\mathrm{s}}(\lambda)$, emissivity of heat source canister

$R_{c}(\lambda)$, reflectivity of filtered converter

$\mathrm{Q}(\lambda)$, quantum efficiency of PV cell 


\section{EMISSION OF BLACK BODY AND OF TUNGSTEN CANISTER $\left(1150^{\circ} \mathrm{C}\right)$ AND ABSORPTION OF FILTERED CONVERTER $\left(0^{\circ} \mathrm{C}\right)$}

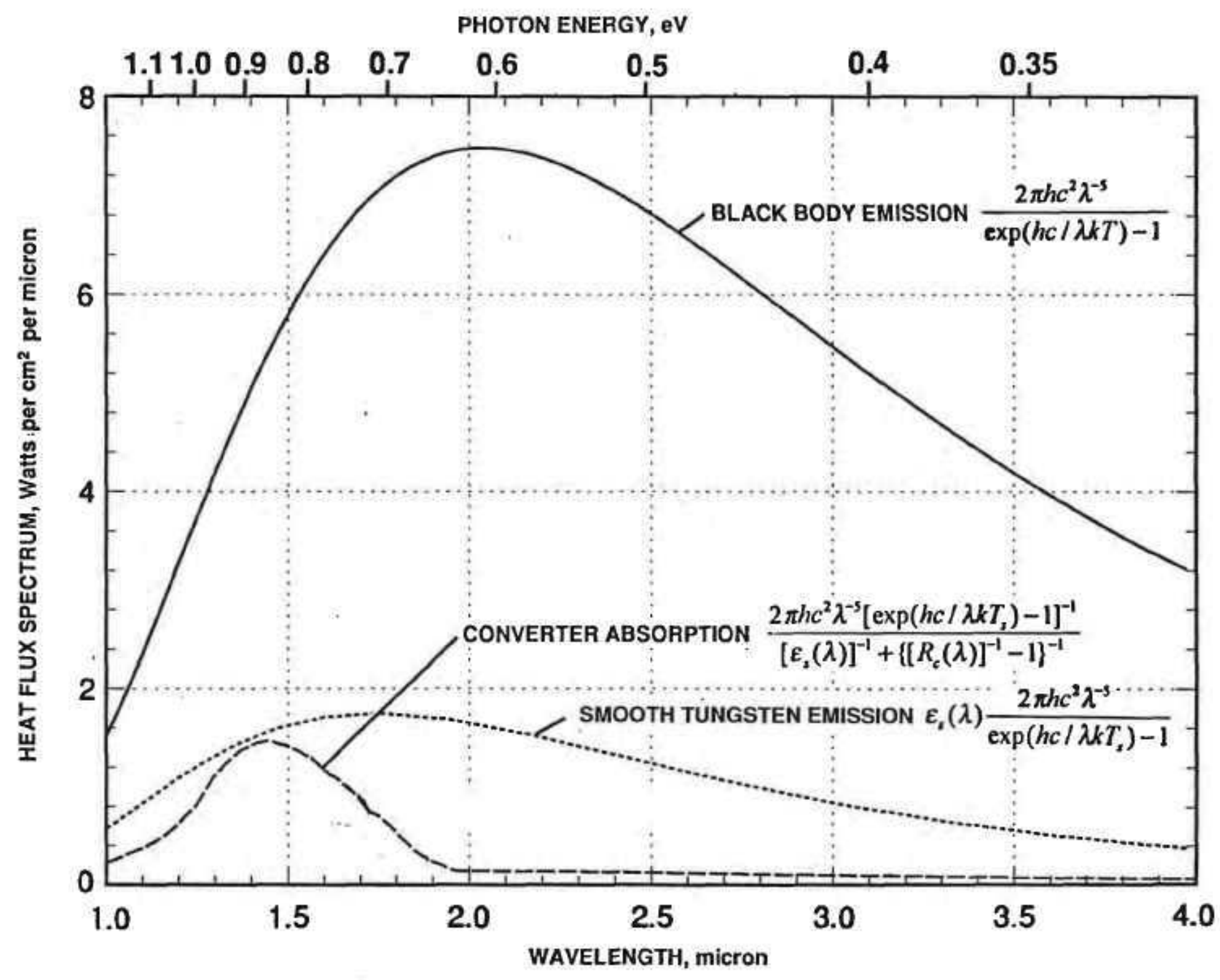




\section{Illustrative Example: ABSORBED PHOTON FLUX AND GENERATED ELECTRON FLUX SPECTRA}

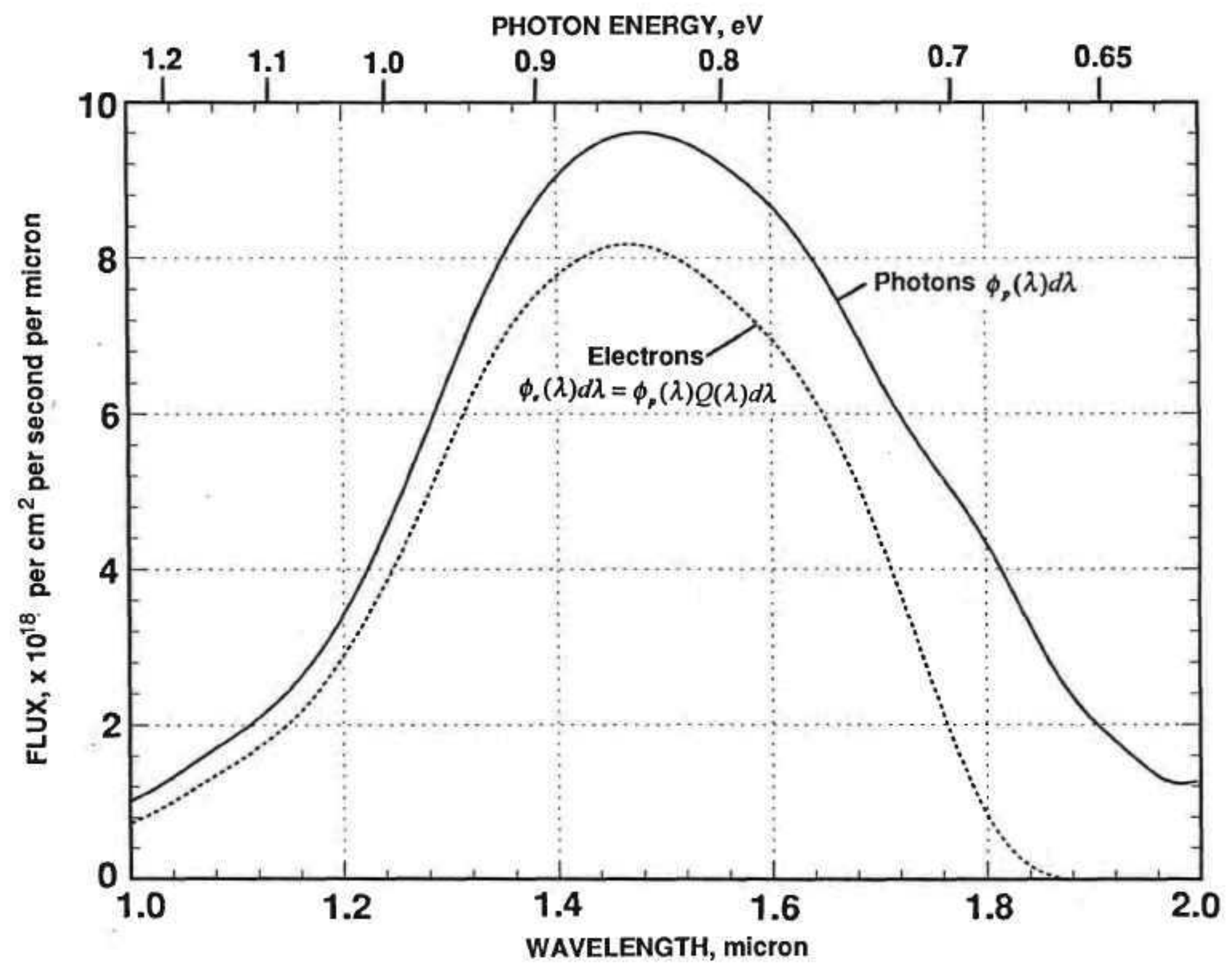




\section{EFFECT OF SOURCE TEMPERATURE ON NET HEAT FLUX ABSORBED BY CONVERTER}

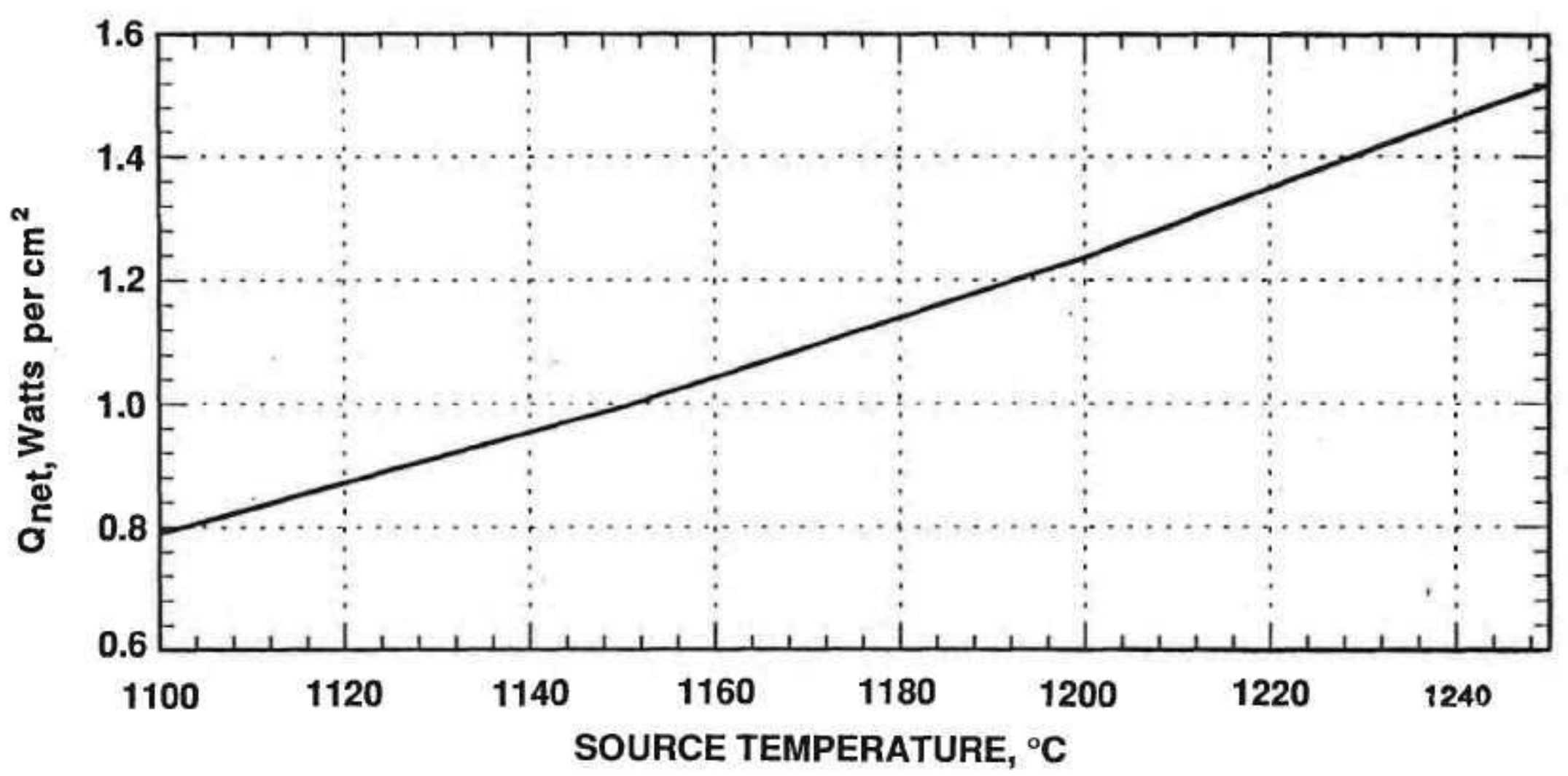

- CONCLUSION: Converter temperature has no effect on net heat flux 


\section{EFFECT OF SOURCE AND CELL TEMPERATURES ON MAXIMUM OUTPUT POWER DENSITY OF CONVERTER}

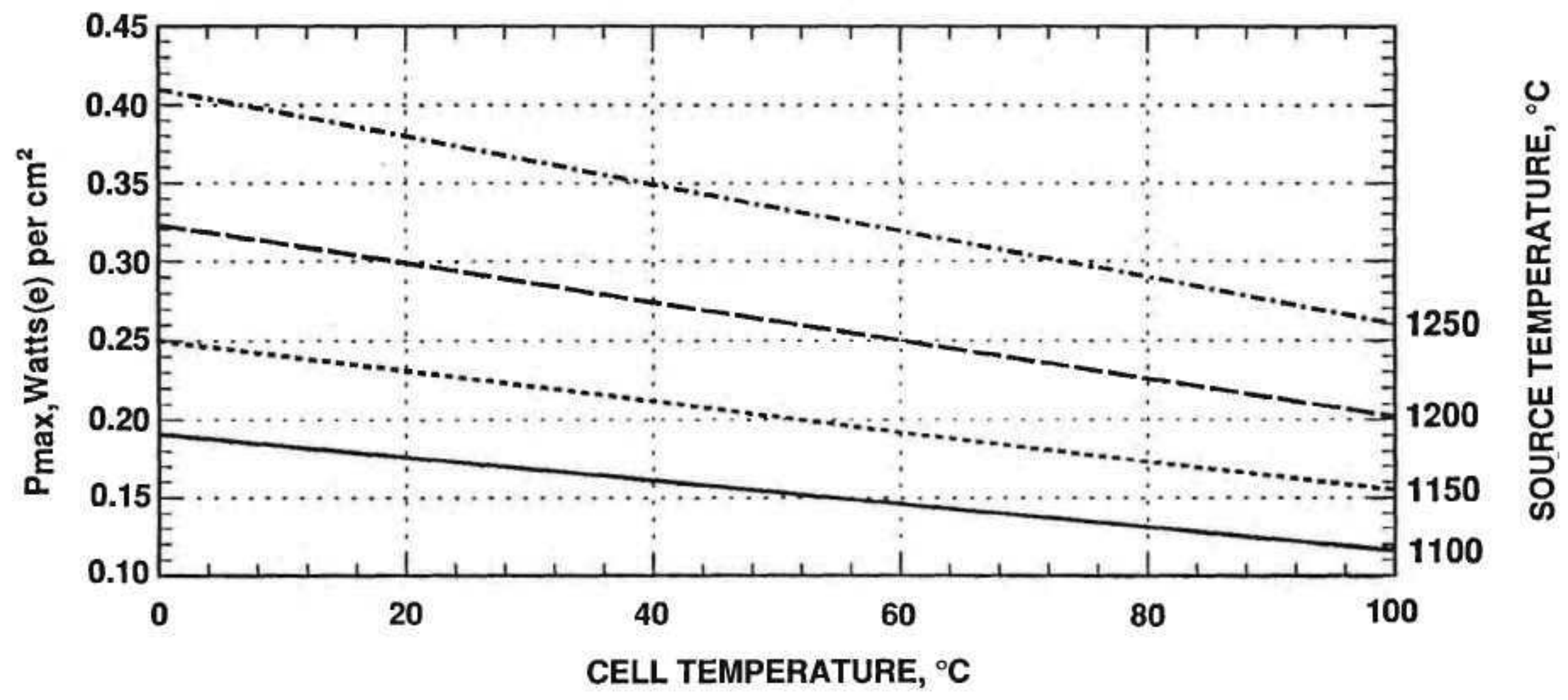

- CONCLUSION: Higher source temperature and lower cell temperature increase power output 


\section{EFFECT OF SOURCE AND CELL TEMPERATURES ON EFFICIENCY OF CONVERTER}

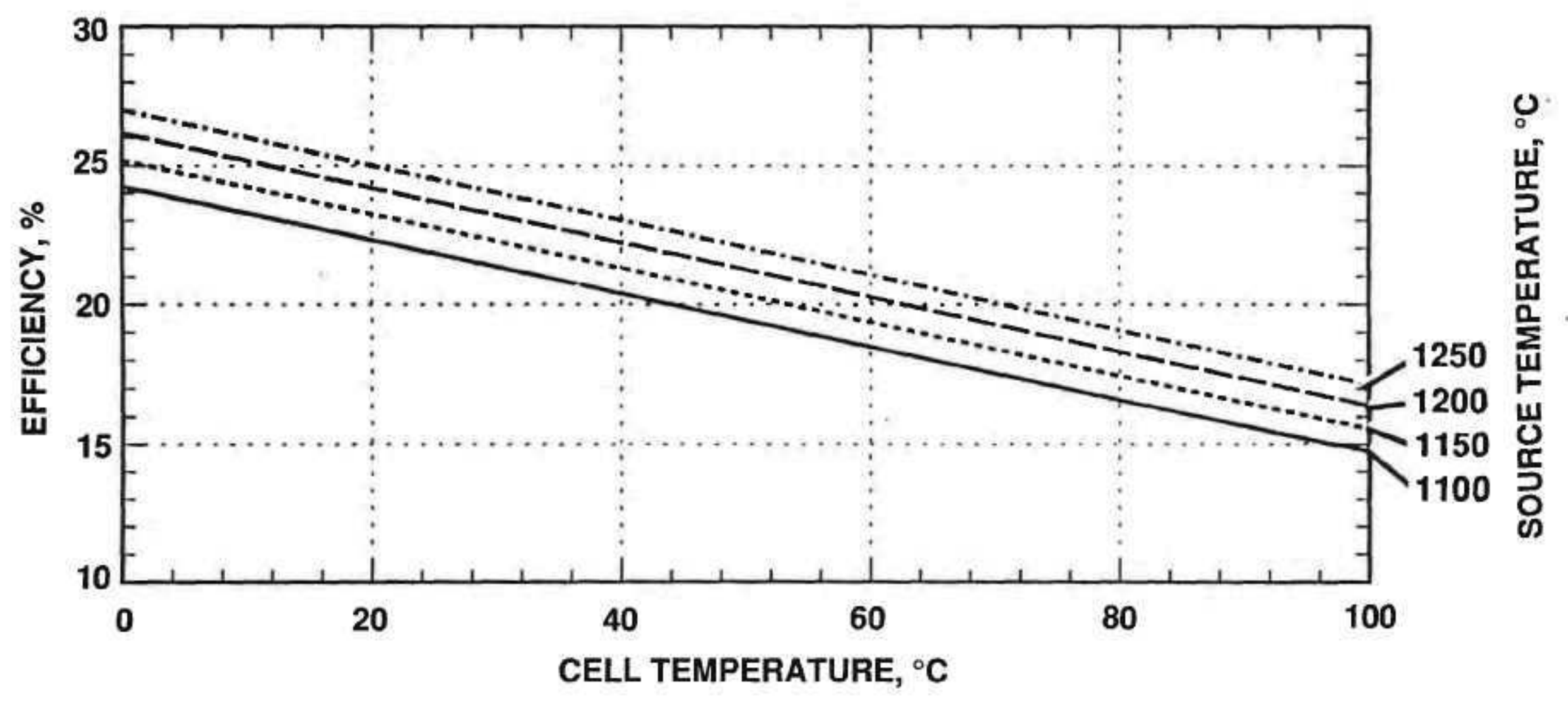

- CONCLUSION: High efficiencies require low cell temperatures 


\section{EFFECT OF NET HEAT FLUX AND CELL TEMPERATURE ON SOURCE TEMPERATURE, POWER DENSITY, AND EFFICIENCY}

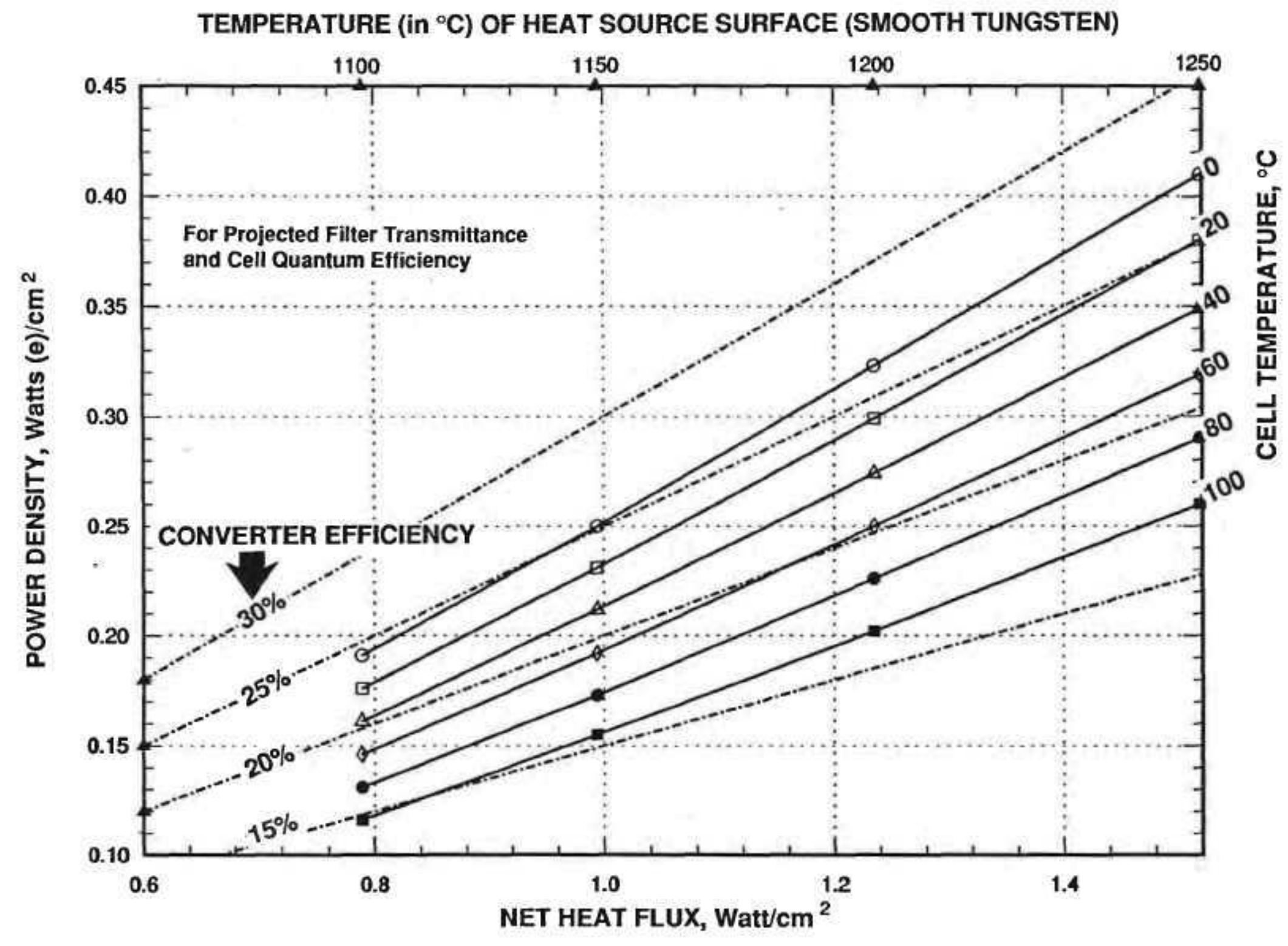




\section{SPECTRAL EMISSIVITY OF TUNGSTEN CANISTER}

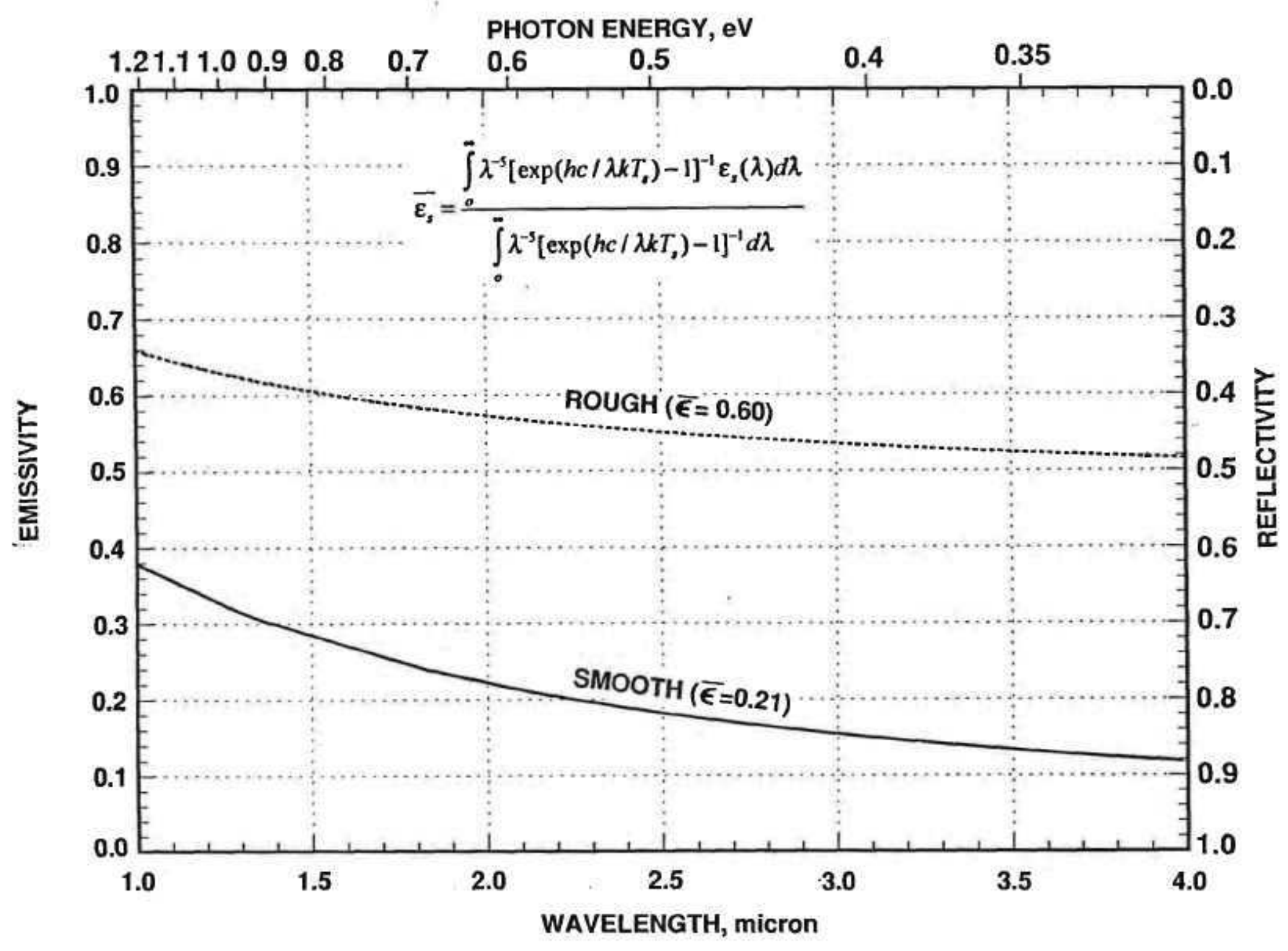




\section{EFFECT OF CANISTER ROUGHNESS ON ITS TEMPERATURE, CONVERTER EFFICIENCY, AND OUTPUT POWER \\ (FOR $0^{\circ} \mathrm{C}$ CELL TEMPERATURE)}

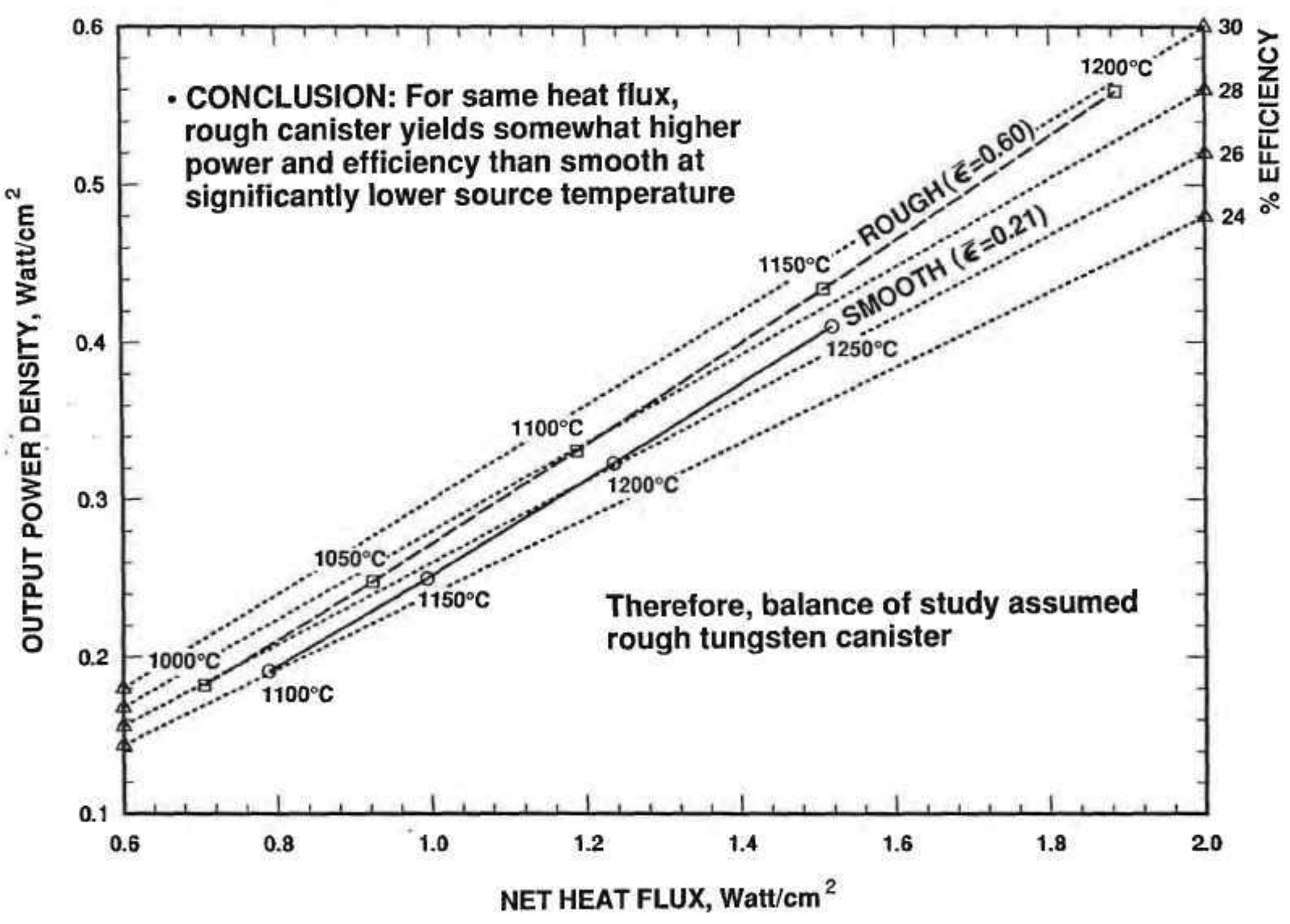




\section{STATIC AND DYNAMIC STRUCTURAL ANALYSES OF RADIATOR FINS}

- RTPV performance is very sensitive to heat rejection temperatures.

- Specific power of RTPVs maximizes at much lower heat rejection temperatures than $\operatorname{RTGS}\left(\sim 0^{\circ} \mathrm{C}\right.$ versus $\left.275^{\circ} \mathrm{C}\right)$.

- Therefore, they require much larger radiator fins, with correspondingly high bending moments during launch.

- Since the radiator is the most massive component of the RTPV system, detailed structural analyses are required to optimize its design.

- The goal is to maximize the RTPV system's specific power without exceeding the allowable stress in the honeycomb skins. 


\section{REQUIRED ALUMINUM SKIN THICKNESS PROFILES TO KEEP TENSILE STRESS BELOW 23 KSI}

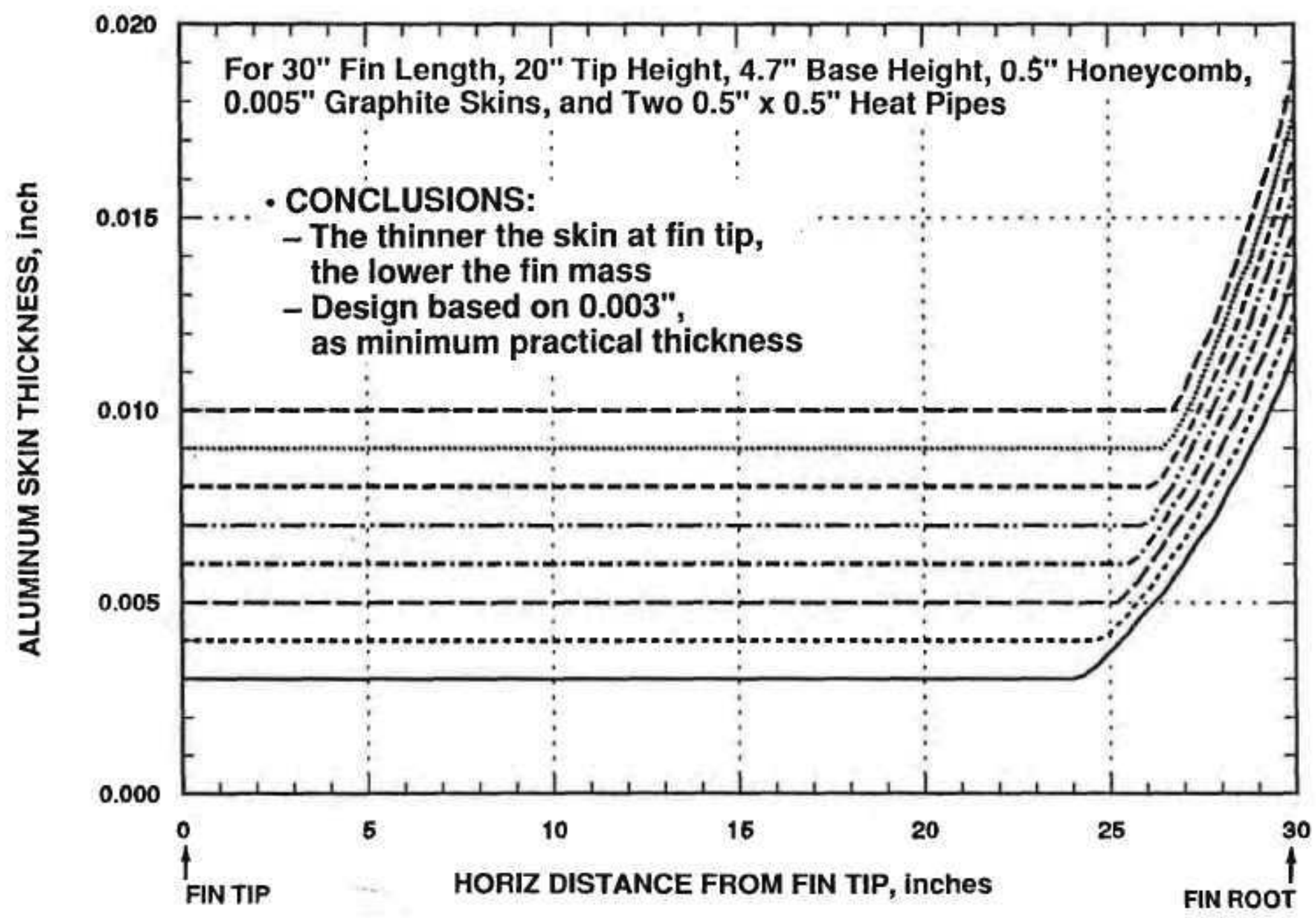




\section{SYSTEM ANALYSIS AND OPTIMIZATION}

- Determining the optimum system design, particularly the fin design that maximizes the system's specific power, requires a coupled thermal and electrical analysis.

- In that analysis, the heat generation rate is known, but the heat source surface temperature $T_{S}$ and cell temperature $\boldsymbol{T}_{c}$ are not. Therefore, the analysis must be carried out iteratively.

- The coupled analysis was carried out by means of:

- A thermal analysis code, SINDA, modified by Fairchild, using a 197-node model, and

- A thermal radiation code, SSPTA, using a 496-surface model.

- Fairchild made two major modifications in the thermal analysis code:

- The net heat flux $q_{\text {net }}$ from the sides of the heat source to the converter cells at each iteration was computed by integration of,

$$
q_{n e t}=2 \pi h c^{2} \int_{0}^{\infty} \frac{\lambda^{-5}\left[\exp \left(h c / \lambda k T_{s}\right)-1\right]^{-1}}{\left[\varepsilon_{s}(\lambda)\right]^{-1}+\left\{[\operatorname{Rc}(\lambda)]^{-1}-1\right\}^{-1}} d \lambda,
$$

with appropriate corrections for gaps between cells and obstruction by the electrical grid;

- The waste heat flowing to the radiator fins was computed by subtracting the converter's electrical power generation rate from the heat generation rate of the heat source.

- The two thermal codes computed a new set of canister and cell temperatures, which were used as inputs in the next iteration. This iterative procedure was repeated until the modified code converged on a consistent solution. 


\section{EFFECT OF GRAPHITE SKIN THICKNESS ON GENERATOR MASS, CELL TEMPERATURE, POWER, EFFICIENCY, AND SPECIFIC POWER}

(For 30" Fin Length, 20" Fin Height, 0.003" Al Skin, 0.38" Honeycomb, $90 \%$ Active Cell Area)
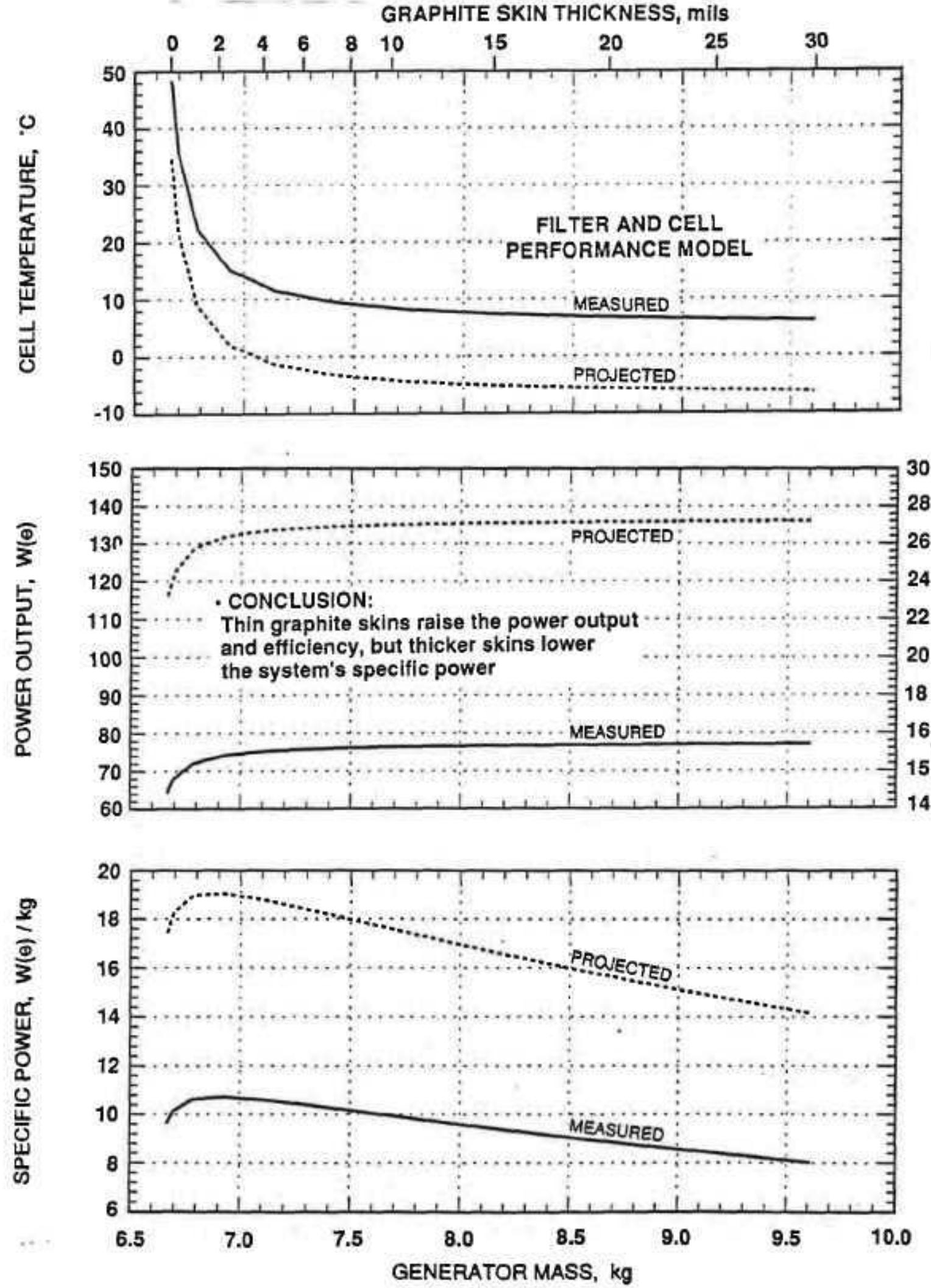


\section{VERSUS GENERATOR MASS(AND IMPLICIT GRAPHITE THICKNESS)}

For various fin lengths and heights, 0.38 " honeycomb, $90 \%$ active cell area, and aluminum skins thickened near fin roots to survive $40-\mathrm{G}$ launch loads

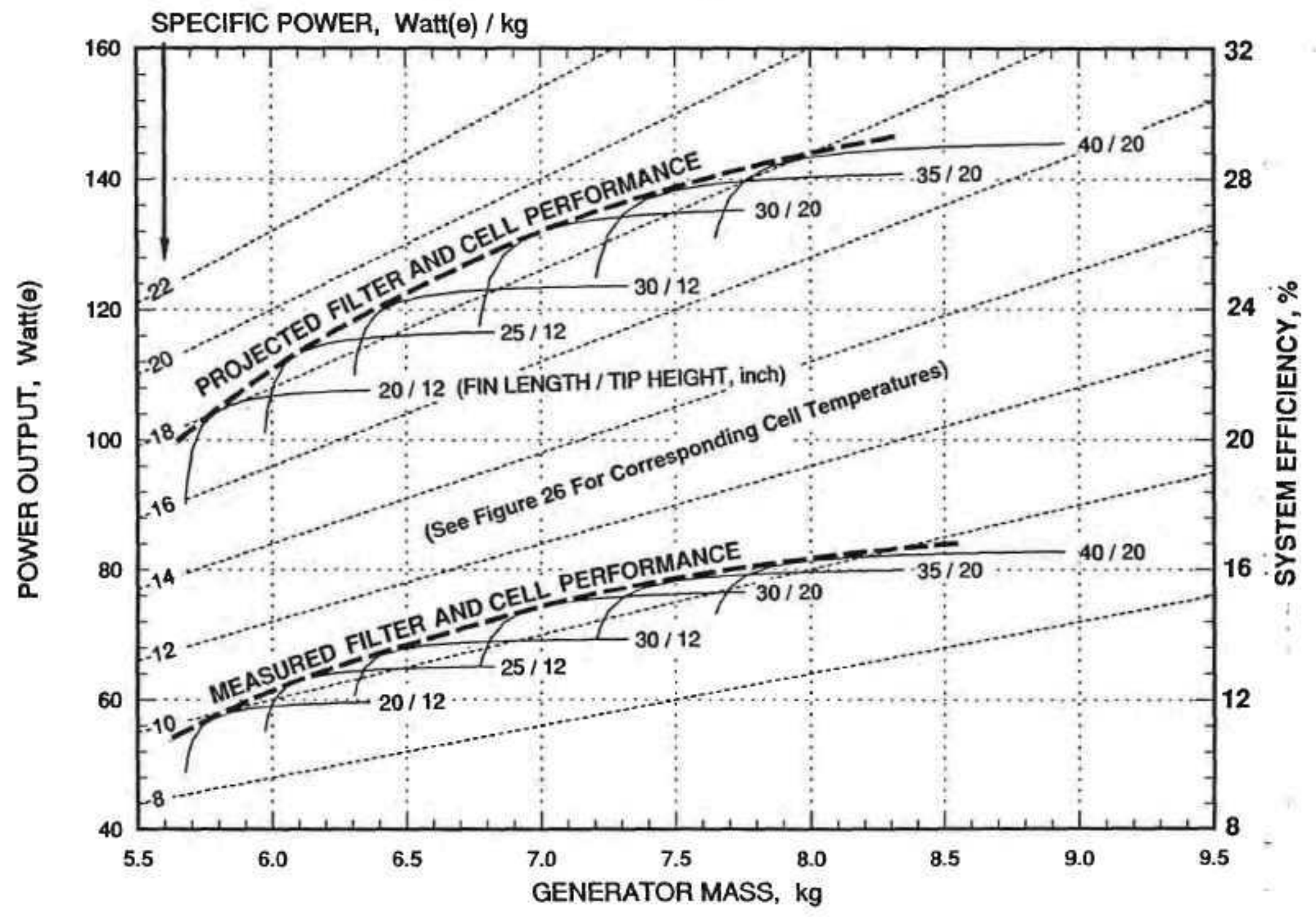




\section{TECHNICAL CONCLUSIONS}

- The "Projected" filter and cell performance model yields much higher specific power than the "Measured" model.

- This demonstrates the importance of verifying that Boeing's "Projected" performance can actually be achieved.

- For both performance models, the RTPV system's specific power is maximized with a 30 " fin length and 20 " fin tip height.

- The optimum is quite broad. Major deviations from the above dimensions result in only modest reductions in specific power.

- Thus, the designer has wide latitude in trading off power versus mass to meet specific mission goals, as illustrated below (for the Projected model):

\section{Goal Low Mass $\underline{\text { Max Sp Power High Power }}$}

Fin Length

Fin Tip Height

Cell Temperature

Power (BOM)

Efficiency (BOM)

Mass

Specific Power
$20 "$

12 "

$68^{\circ} \mathrm{C}$

$103 \mathrm{w}$

$20.6 \%$

$5.7 \mathrm{~kg}$

$18.0 \mathrm{w} / \mathrm{kg}$
$30 "$

20 "

$0^{\circ} \mathrm{C}$

$130 \mathrm{w}$

$26.0 \%$

$7.2 \mathrm{~kg}$

$18.6 \mathrm{w} / \mathrm{kg}$ $40^{\prime \prime}$

$20 "$

$-21^{\circ} \mathrm{C}$

$145 \mathrm{w}$

$29.0 \%$

$8.2 \mathrm{~kg}$

$17.6 \mathrm{w} / \mathrm{kg}$ 


\section{COMPARISON OF RTG/RTPV OPERATING TEMPERATURES}

\begin{tabular}{|l|c|c|c|}
\hline \multicolumn{1}{|c|}{ Generator } & RTG & \multicolumn{2}{c|}{ RTPV } \\
\hline Performance Model & Unicouple & Measured & Projected \\
\hline Generator Mass, kg & 15.4 & 7.2 & 7.2 \\
Number of Heat Source Modules & 5 & 2 & 2 \\
Thermal Power, watts & 1250 & 500 & 500 \\
\hline Operating Temperatures, ${ }^{\circ} \mathrm{C:}$ & & & \\
Clad &.$\cdot 1326$ & 1153 & 1210 \\
Aeroshell & 1060 & 1062 & 1128 \\
Canister & none & 1034 & 1103 \\
Converter & $990 / 267$ & 10.6 & -2.2 \\
Radiator Heatpipe & none & -9.3 & -19.4 \\
\hline
\end{tabular}

\section{CONCLUSIONS:}

- The most critical temperature is clad temperature, since clad temperatures above $1330^{\circ} \mathrm{C}$ could lead to excessive grain growth and iridium embrittlement.

- Clad temperatures are substantially lower in RTPV than in RTG, due to retention of helium in canister.

- Separate results show that even with a leaky canister the RTPV clad temperature would not exceed the $1330^{\circ} \mathrm{C}$ limit.

- The RTPV's converter temperature is much lower than the RTG's, eliminating temperature-induced performance degradation. 
COMPARATIVE MASS BREAKDOWN (kg)

\begin{tabular}{|c|c|c|}
\hline Generator & RTG & RTPV \\
\hline $\begin{array}{l}\text { GPHS Modules (number) } \\
\text { Fuel }\left(\mathrm{PuO}_{2}\right) \\
\text { Clads (Ir) } \\
\text { Graphitics }\end{array}$ & $\begin{array}{l}(5) \\
2.98 \\
1.17 \\
3.09 \\
\end{array}$ & $\begin{array}{l}(2) \\
1.19 \\
0.47 \\
1.23\end{array}$ \\
\hline $\begin{array}{l}\text { Canister (Mo) } \\
\text { Structural Supports } \\
\text { Multifoil Insulation (Mo) }\end{array}$ & $\begin{array}{l}0.00 \\
1.07 \\
1.44\end{array}$ & $\begin{array}{l}0.63 \\
0.00 \\
0.09\end{array}$ \\
\hline $\begin{array}{l}\text { Converter Elements, etc. } \\
\text { Housing, etc. } \\
\text { Radiator }\end{array}$ & $\begin{array}{l}2.15 \\
2.90 \\
0.89\end{array}$ & $\begin{array}{l}0.17 \\
0.53 \\
2.85\end{array}$ \\
\hline TOTAL & 15.59 & 7.16 \\
\hline
\end{tabular}

* Parabolic radiator reduces generator mass to $6.87 \mathrm{~kg}$, before credit for reduced antenna mass.

\section{CONCLUSIONS:}

- RTPV mass is less than half the RTG mass.

- RTPV mass of $7.2 \mathrm{~kg}$ meets and greatly exceeds JPL's mass reduction goal of $9.5 \mathrm{~kg}$ for PFF power source.

- Radiator mass is only $5 \%$ of RTG mass but $40 \%$ of RTPV mass.

- RTPV requires $60 \%$ fewer GPHS modules than RTG. Since these are the dominant cost component of radioisotope power system, $60 \%$ reduction would result in major cost savings. 


\section{EFFECT OF RADIATOR GEOMETRY ON BOM RTPV PERFORMANCE}

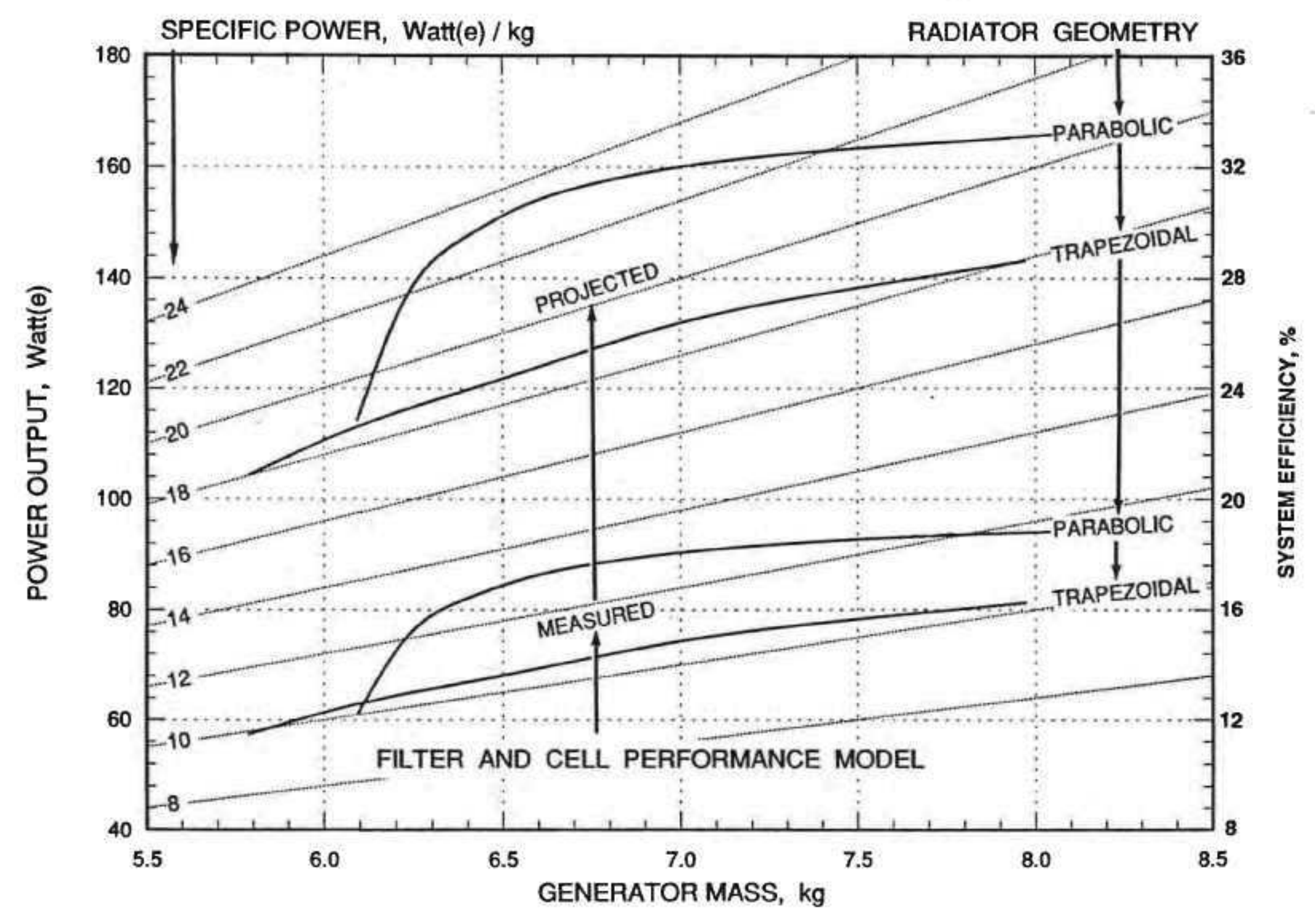




\section{RTG/RTPV PERFORMANCE COMPARISON (BOM)}

\begin{tabular}{|l|c|c|c|c|}
\hline \multicolumn{1}{|c|}{ Generator } & RTG & \multicolumn{3}{c|}{ RTPV } \\
\hline \multicolumn{1}{|c|}{ Radiator Fins } & Rectangular & \multicolumn{2}{c|}{ Trapezoidal } & Parabolic \\
\hline Performance Model & Unicouple & Measured & \multicolumn{2}{c|}{ Projected } \\
\hline Generator Mass, kg & 15.6 & 7.2 & 7.2 & 6.6 \\
Number of Heat Source Modules & 5 & 2 & 2 & 2 \\
Thermal Power, watts & 1250 & 500 & 500 & 500 \\
\hline Output Voltage & 19 & 26.5 & 28.6 & 31.4 \\
Output Current, amps & 4.6 & 2.9 & 4.7 & 4.9 \\
Output Power, watts & 87 & 76 & 134 & 153 \\
System Efficiency, \% & 7.0 & 15.1 & 26.8 & 30.7 \\
Specific Power, watts/kg & 5.7 & 10.4 & 18.5 & 23.3 \\
\hline
\end{tabular}

- For the more conservative (measured) performance model:

- Replacement of the RTG with the RTPV would roughly double the generator's efficiency and specific power.

- For the improved (projected) performance model:

- Replacement of the RTG with the RTPV would roughly quadruple the generator's efficiency and triple or quadruple its specific power.

- Its much-greater-than-specified power output could be used for faster postencounter data transmission to Earth, which would significantly reduce the mission's operating costs.

- If feasible, the concept of combining the RTPV. radiator with the parabolic antenna of the PFF would substantially increase the power, system efficiency, and specific power of the generator. 


\section{RTPV TECHNOLOGY STATUS}

- RTPVs have the potential for clearly superior performance, but JPL has baselined the use of RTGs for PFF because their technology is much more mature.

- Boeing recently conducted a scaled-down simulated RTPV system test for JPL, but this test was severely limited by funding and time constraints, which prevented construction and optimization of new cells and filters.

- This forced the use of unoptimized and unmatched components left over from previous solar programs, too few to cover more than a small fraction of the simulated heat source's surface area.

- Because of these limitations, the reported test results - while encouraging $(13.3 \%$ measured efficiency at $1010^{\circ} \mathrm{C}$ ) - were far from demonstrating the projected potential of the RTPV system.

- Development and demonstration of technology readiness for long missions is usually a very time-consuming process, but there are several aspects of the RTPV design that may greatly reduce the need for lengthy life tests. 


\section{FACTORS THAT MAY GREATLY REDUCE NEED FOR LENGTHY LIFE TESTS OF RTPV DESIGN}

- Heat source employs standard GPHS modules that have already been developed, safety-tested, lifetested, and successfully used in RTGs on previous flight programs.

- GPHS modules are completely enclosed in canister to prevent access of sublimates and outgassing products to PV cells.

- Canister is coated with tungsten to minimize sublimation. At $1100^{\circ} \mathrm{C}$, tungsten sublimation is only $10^{-6}$ atomic monolayers in ten years.

- Filters employ stable gold rather than exotic new materials with unknown degradation effects. Performance improvement requires geometric rather than chemical changes.

- TPV cells and arrays are derivatives of solar system PV arrays and use similar fabrication methods.

- Primary radiation (alphas) stopped by canister. Neutron and gamma emission orders of magnitude less than reactors, and their effect on PV cells can be measured quickly by accelerated tests.

- Lengthy tests to determine temperature-induced degradation effects are not needed, because cells operate cold $\left(0-10^{\circ} \mathrm{C}\right)$. 


\section{PROGRAMMATIC CONCLUSIONS}

- The previously listed factors can greatly reduce the need for long-term tests, and may make it possible to establish the RTPV system's flight readiness within the required PFF schedule, if their development is initiated soon.

- The very substantial improvements in system efficiency and specific power that would result from successful development of radioisotope thermophotovoltaic generators by DOE and/or NASA would make such systems of great value not only for the Pluto Fast Flyby mission but also for other missions requiring small, long-lived, low-mass generators in the future. 